\title{
Bacterial Translocation as Inflammatory Driver in Crohn's Disease
}

\author{
Raquel Linares ${ }^{1}$, Rubén Francés ${ }^{1,2,3}$, Ana Gutiérrez ${ }^{2,3,4 * \dagger}$ and Oriol Juanola ${ }^{5,6 * \dagger}$ \\ ${ }^{1}$ Hepatic and Intestinal Immunobiology Group, Department of Clinical Medicine, Miguel Hernández University, San Juan \\ de Alicante, Spain, ${ }^{2}$ CIBERehd, Instituto de Salud Carlos III, Madrid, Spain, ${ }^{3}$ Instituto ISABIAL, Hospital General \\ Universitario de Alicante, Alicante, Spain, ${ }^{4}$ Servicio de Medicina Digestiva, Hospital General Universitario de Alicante, \\ Alicante, Spain, ${ }^{5}$ Translational Research Laboratory, Gastroenterology and Hepatology, Ente Ospedaliero Cantonale, \\ Lugano, Switzerland, ${ }^{6}$ Faculty of Biomedical Sciences, Universitá della Svizzera Italiana, Lugano, Switzerland
}

OPEN ACCESS

Edited by:

Marco Fidaleo,

Sapienza University of Rome, Italy

Reviewed by:

Javier P. Gisbert,

Princess Royal University Hospital,

Spain

Alexander Sinclair Easton,

Dalhousie University, Canada

Jefferson Antonio Leite,

Universidade de São Paulo, Brazil

*Correspondence:

Ana Gutiérrez

gutierrez_anacas@gva.es

Oriol Juanola

oriol.juanola.juarez@usi.ch

tThese authors share last authorship

Specialty section:

This article was submitted to

Molecular and Cellular Pathology,

a section of the journal

Frontiers in Cell and Developmental

Biology

Received: 30 April 2021

Accepted: 30 July 2021

Published: 07 September 2021

Citation:

Linares $R$, Francés $R$, Gutiérrez $A$

and Juanola O (2021) Bacterial

Translocation as Inflammatory Driver

in Crohn's Disease.

Front. Cell Dev. Biol. 9:703310.

doi: 10.3389/fcell.2021.703310
Crohn's disease $(C D)$ is a chronic inflammatory disorder of the gastrointestinal tract responsible for intestinal lesions. The multifactorial etiology attributed to CD includes a combination of environmental and host susceptibility factors, which result in an impaired host-microbe gut interaction. Bacterial overgrowth and dysbiosis, increased intestinal barrier permeability, and altered inflammatory responses in patients with CD have been described in the past. Those events explain the pathogenesis of luminal translocation of bacteria or its products into the blood, a frequent event in $C D$, which, in turn, favors a sustained inflammatory response in these patients. In this review, we navigate through the interaction between bacterial antigen translocation, permeability of the intestinal barrier, immunologic response of the host, and genetic predisposition as a combined effect on the inflammatory response observed in CD. Several lines of evidence support that translocation of bacterial products leads to uncontrolled inflammation in CD patients, and as a matter of fact, the presence of gut bacterial genomic fragments at a systemic level constitutes a marker for increased risk of relapse among CD patients. Also, the significant percentage of CD patients who lose response to biologic therapies may be influenced by the translocation of bacterial products, which are well-known drivers of proinflammatory cytokine production by host immune cells. Further mechanistic studies evaluating cellular and humoral immune responses, gut microbiota alterations, and genetic predisposition will help clinicians to better control and personalize the management of CD patients in the future.

Keywords: Crohn's disease, bacterial translocation, intestinal permeability, dysbiosis, NOD2, inflammatory response, anti-TNF- $\alpha$

\section{INTRODUCTION}

Crohn's disease (CD) is a type of chronic idiopathic inflammatory bowel disease (IBD) that may affect any part of the gastrointestinal (GI) tract and causes inflammatory, stricturing, or penetrating intestinal lesions (Torres et al., 2017). The prevalence of CD has increased worldwide in the past 50 years, and it imposes a considerable economic burden on health systems as it requires new and costly treatment options and trained specialists to manage CD patients (Ng et al., 2017; 
Windsor and Kaplan, 2019). The etiology of CD includes several aspects involving environmental factors, genetic susceptibility, and the impaired immune interaction of the host with the intestinal microbiota (Chang, 2020).

The immune response in $\mathrm{CD}$ is induced by different cell types such as neutrophils and macrophages that act together with epithelial cells in promoting and generating inflammatory phenomena by releasing soluble factors as tumor necrosis factoralpha (TNF- $\alpha)$ and antimicrobial peptides like defensins and cathelicidins (Ramasundara et al., 2009; Gutiérrez et al., 2011). Intestinal bacteria are key contributors to the onset, perpetuation, and pathogenesis of chronic intestinal inflammation suggesting a disturbed immune gut response to bacterial antigens. This hypothesis is supported by several lines of evidence: (1) CD clinical lesions are mainly located in the distal ileum and colon, which are regions of high microbial concentration, (2) several studies demonstrate that luminal bacteria are necessary for the development of disease in murine models (Harper et al., 1985; Elson et al., 2005), and (3) CD patients present dysbiosis or reduced biodiversity in the composition of their gut microbiota associated with increased bacteria with proinflammatory properties and less anti-inflammatory bacterial species (Willing et al., 2010; Chassaing and Darfeuille-Michaud, 2011; Manichanh et al., 2012).

Our gut epithelial cells act as a physical barrier between the lumen of the GI tract and the inner mucosa contributing to nutrient and fluid absorption and impeding intact bacteria penetration. Genetic polymorphisms affecting barrier function or chronic inflammation may contribute to an abnormal intestinal permeability and, therefore, favor bacterial translocation (BT) and aggravate the course of disease. Genes associated with intestinal homeostasis involve autophagy, innate and adaptive immune regulation, microbial defense, or barrier function, among others (Franke et al., 2010; Khor et al., 2011). Some risk loci might influence immunological function such as nucleotidebinding oligomerization domain-containing 2 (NOD2), which encodes an intracellular receptor for muramyl dipeptide (MDP), a component in bacterial cell walls (Inohara et al., 2003). In this regard, three common variants of NOD2 loci apparently confer susceptibility to CD (Hugot et al., 2001) suggesting that an impaired response to bacterial antigens may contribute, and further studies indicate that low Foxp3+ regulatory T-cell (Treg) counts and a variant NOD2 genotype can be markers of loss of response to anti-TNF- $\alpha$ in CD patients (Juanola et al., 2014).

In this review, we integrate the effect of bacterial antigen translocation, the host immunologic response, and the genetic background in the inflammatory response observed in CD.

\section{GUT-DERIVED BACTERIAL ANTIGEN TRANSLOCATION}

Bacterial translocation is known as the passage of bacteria or its products, such as endotoxins, from the GI tract to mesenteric lymph nodes and systemic circulation (Alexander et al., 1990). This event has been demonstrated in CD by several studies in which the presence of bacteria in the lymph nodes
(Takesue et al., 2002; Peyrin-Biroulet et al., 2012; O’Brien et al., 2014) or bacterial genomic fragments in the blood (Gutiérrez et al., 2009, 2011, 2014) are detected. Bacterial passage from the bowel lumen is a common phenomenon in $\mathrm{CD}$, and it is involved in the pathogenesis by inducing, perpetuating, or exacerbating an inflammatory state (Swank and Deitch, 1996). The risk factors influencing BT are mainly intestinal bacterial overgrowth or dysbiosis, increased intestinal permeability, and local and systemic immunological alterations and can be followed in Table 1.

Human species have evolved with the symbiotic intestinal microbiota, which is composed of 10 (Franke et al., 2010) to 10 (Inohara et al., 2003) microorganisms including bacteria, fungus, archaea, and viruses whose total genome represents 100 times our own genome (Gill et al., 2006). GI microbiota is mainly composed of four bacterial divisions: Firmicutes, Bacteroidetes, Proteobacteria, and Actinobacteria, but the composition and the luminal concentrations of bacterial species may vary in the different GI tract regions (Eckburg et al., 2005). These commensal bacteria provide an abundant source of antigens that can activate pathogenic immune responses resulting in chronic intestinal inflammation and clinical manifestations of CD-susceptible patients.

An increase in the number and/or altered composition of microbial species in the small bowel is known as small intestinal bacterial overgrowth (SIBO), which is potentially caused by fistulae, strictures, a slowed intestinal transit, low acid gastric secretion, and altered local immune activity such as common variable immunodeficiencies associated with low IgA (Pignata et al., 1990; Husebye, 2005; Klaus et al., 2009). Patients with CD show some of these features, so they are predisposed to develop SIBO and a complicated clinical course of CD. Bacterial overgrowth or abnormal microflora (dysbiosis) within the gut have been described in the past in CD patients (Manichanh et al., 2006; Lupp et al., 2007; Sartor, 2008), and they are present in the early stages of CD being further amplified by antibiotic treatment (Gevers et al., 2014; KowalskaDuplaga et al., 2019). Also, healthy first-degree relatives of CD patients show an altered microbiota suggesting a genetic predisposition to develop this condition (Joossens et al., 2011). In addition, there are differences in the diversity of microbiota depending on disease activity: between inflamed areas in different IBD phenotypes, and in microbial metabolism (Forbes et al., 2016; Franzosa et al., 2019; Lloyd-Price et al., 2019). Overall, the dysbiotic profile in CD patients is characterized by a decrease in Bacteroidetes and Firmicutes, and an increase in Enterobacteriaceae microbial populations (Frank et al., 2007; Kostic et al., 2014; Khan et al., 2019). The decrease in Faecalibacterium prausnitzii has been widely observed (Hedin et al., 2016), which is a bacterium with an important role in the regulation of Th17 cells (Zhang M. et al., 2019). In fact, this species, together with Lactobacillus and Bifidobacterium, among others, display a protective role in intestinal inflammation (Hrdý et al., 2020; Singh et al., 2020). Additionally, reduced abundance of Lachnospiraceae and Ruminococcaceae families producing short-chain fatty acids (SCFAs) are associated with poor response to TNF- $\alpha$ biologic therapy and frequent relapses 
TABLE 1 | Risk factors for bacterial translocation in Crohn's disease include intestinal dysbiosis, altered intestinal integrity, and immune dysfunction.

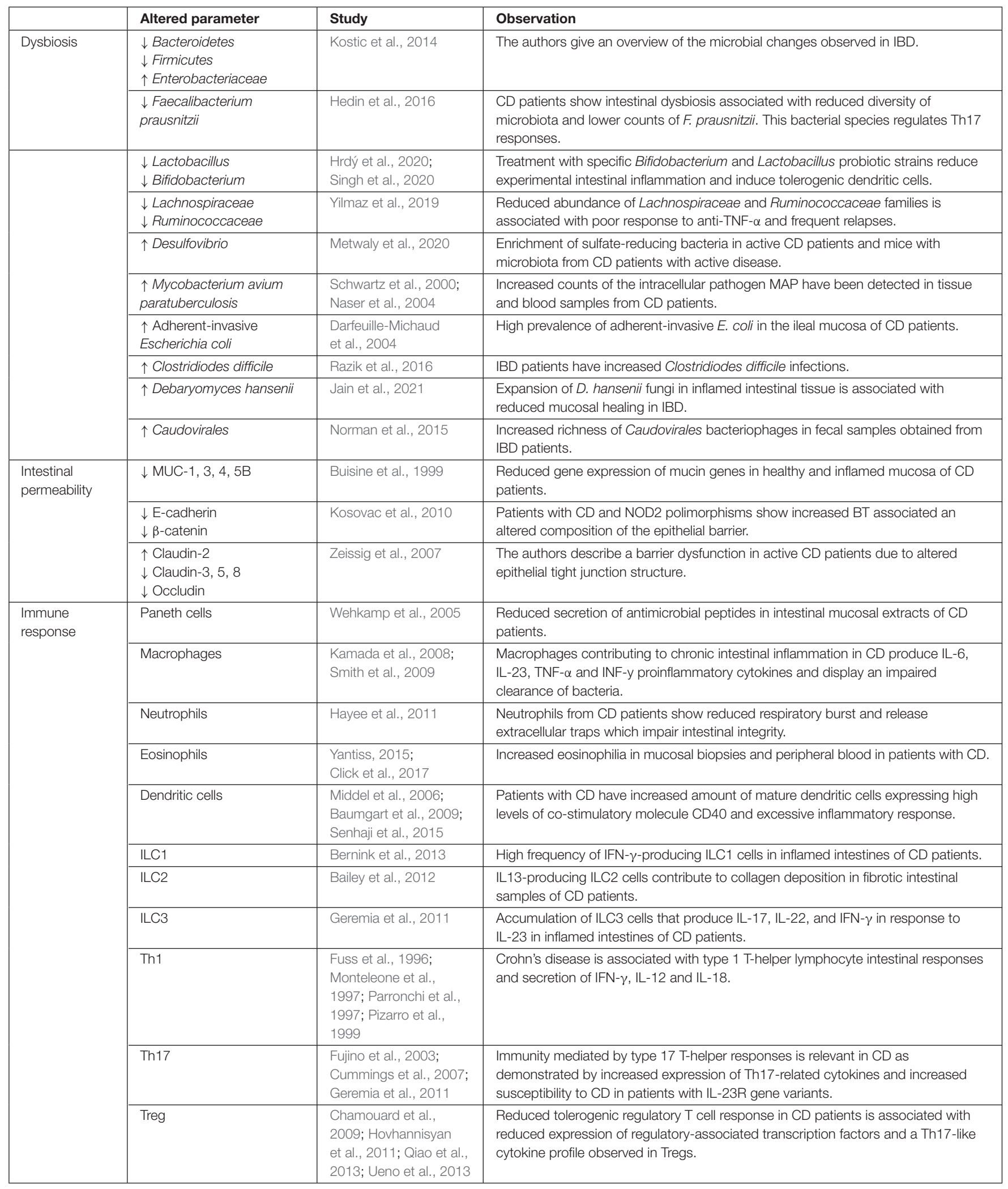


in CD (Yilmaz et al., 2019). Also, the altered gut microbiome is associated with enrichment of sulfate-reducing bacteria in active $\mathrm{CD}$ patients and mice with microbiota from CD patients with active disease (Metwaly et al., 2020).

Decreased complexity and diversity of commensal bacteria that promote intestinal homeostasis play a critical role in CD due to the disrupted capacity of the microbiota to exclude pathogens, which can favor inflammatory responses. Mycobacterium avium paratuberculosis (MAP) is an obligate intracellular pathogen detected in intestinal samples of CD patients by different molecular biology and cell culture techniques (Mishina et al., 1996; Schwartz et al., 2000). The contribution of MAP in the pathogenesis of $\mathrm{CD}$ was further confirmed by the detection of cultivable MAP in the blood of patients with CD (Naser et al., 2004). Therefore, MAP has been proposed as a potential etiologic infectious agent of $\mathrm{CD}$, although this hypothesis remains to be validated (McNees et al., 2015). Another microbial pathogen such as adherent/invasive $E$. coli has been detected in biological samples of the ileum in patients with CD (Darfeuille-Michaud et al., 2004), and more interestingly, there is an increased severity of $\mathrm{CD}$ in those patients with high levels of serum antibodies detecting porin $\mathrm{C}$ present in the outer membrane of E. coli (Mow et al., 2004). Clostridiodes difficile is also an opportunistic pathogen in IBD patients frequently causing symptoms ranging from diarrhea to fulminant colitis and death (D'Aoust et al., 2017). IBD patients have a higher risk of Clostridiodes difficile infection, which is associated with longer hospitalization periods and increased resource costs (Nguyen et al., 2008; Razik et al., 2016). Despite literature showing a clear perturbation in IBD microbiota, it is not a clear cause-effect link. It is known that the inflammatory state in $\mathrm{CD}$ affects the microbial composition (Craven et al., 2012) but also that IBD microbiota can induce intestinal inflammation (Nagao-Kitamoto et al., 2016). In this regard, treatments addressed to restore healthy gut microbiota in IBD, such as administration of prebiotics and probiotics (Limketkai et al., 2020), antibiotic therapy (Castiglione et al., 2003), and fecal microbiota transplantation (Britton et al., 2020) need further investigations.

Antibiotics used on patients with inflammatory intestinal disease are targeted toward bacteria that, in turn, favor the colonization of intestinal niches by other members of the intestinal microbiota. Relevance of fungal microbiota dysbiosis have been described in patients with CD (Liguori et al., 2016), and antibodies to anti-Saccharomyces cerevisiae have been detected in CD (Seow et al., 2009). The interaction between intestinal fungi and host immune system occurs through receptors of the host innate immune system such as Dectin-1 (Iliev et al., 2012). Recently, poor mucosal healing in CD has been associated with overgrowth of Debaryomyces hansenii underlying that not only bacteria but also fungi species may modulate the intestinal inflammatory disease (Jain et al., 2021). Relevance of fungi in mucosal healing was evidenced in the study of Jain et al. (2021) by detecting the presence of $D$. hansenii in intestinal wounds with impaired healing after antibiotic treatment, whereas the administration of antifungal amphotericin B reduced fungi detection and increased wound regeneration. Oral gavage of $D$. hansenii altered crypt regeneration in conventional mice not treated with antibiotics and increased the severity of experimental colitis. The authors confirmed that macrophages were recruited in the areas colonized by D. hansenii and that CCL5 and type I IFN secreted by myeloid cells are required to alter mucosal healing, supporting CCL5 as a potential target in CD. Additionally, changes in the enteric virome associated with an expansion of Caudovirales bacteriophages have been described in patients with CD (Norman et al., 2015). Viral infection by the enteric murine norovirus in experimental models carrying the CD susceptibility gene ATG16L1 is associated with multiple pathologic abnormalities in the intestine (Cadwell et al., 2010). Even if increasing knowledge is required to understand the interactions existing between intestinal microbiota and the host during $\mathrm{CD}$, we can assume that intestinal microbes play an active role in the progression of intestinal inflammatory disease.

The intestinal epithelium acts as a physical and antimicrobial barrier against pathogenic bacteria and environmental antigens (Okamoto and Watanabe, 2016). When the intestinal barrier is disrupted, commensal microbiota, which in physiological conditions exist in a symbiotic relationship with humans, can cross the epithelium and contribute to intestinal inflammation. The intestinal mucosal barrier is composed of both the outer mucus layer, which is comprised by secreted mucinous and antibacterial components, and the inner subepithelial elements involving the immune system (Salim and Söderholm, 2011). Epithelial cells together with M-cells, mucus-secreting globet cells and Paneth cells form a polarized monolayer structure linked by apical junctions which are formed by tight junctions and subadjacent adherens junctions (Turner, 2009). The junctional complex is composed of transmembrane and peripheral proteins including actin, claudins, occludins, zonula occludens (ZO)-1, and junctional adhesion molecules. Enteric glial cells located in the intestinal mucosa also regulate the permeability of the intestinal epithelial barrier in CD by producing 15-hydroxyeicosatetraenoic acid, a polyunsaturated fatty acid that increases the expression of ZO-1 (Pochard et al., 2016). Crucial functions of the intestinal barrier include maintenance of intestinal homeostasis by allowing the absorption of essential nutrients, as well as tolerance to commensal bacteria, and prevention of the entry of injurious bacterial components. A disturbance in one of the components that are involved in the epithelial barrier function can increase its permeability leading to an impaired ability to avoid BT. Altered expression of mucins $1,3,4$, and $5 \mathrm{~B}$ in the ileal mucosa of patients with CD favor the binding of microbes to the intestinal surface (Buisine et al., 1999). Additionally, the protein composition of tight and adherens junctions on intestinal cell-cell contacts is altered on CD patients (Zeissig et al., 2007; Kosovac et al., 2010). Disturbances in the permeability of the intestinal barrier associated with a derangement of the tight junction were also probed by freeze-fracture electron microscopic analysis (Marin et al., 1983a,b). Reduced integrity of the intestinal barrier leads to an increased absorption of luminal microbial antigens and serum concentrations of endotoxins, lipopolysaccharide-binding protein (LBP), and CD14s, which are markers of disease activity in CD (Pastor Rojo et al., 2007; Lakatos et al., 2011).

The importance of genetic background as a contributing factor to the impaired barrier function in $\mathrm{CD}$ comes from 
studies with first-degree relatives of patients with $\mathrm{CD}$ showing that NOD2 3020insC mutation is associated with increased mucosal permeability (Irvine and Marshall, 2000; Buhner et al., 2006). Also, a gene polymorphism in adherens junction protein E-cadherin (CDH1 gene) was observed in some patients with $\mathrm{CD}$ resulting in a cytoplasmic mis-localization of the protein pointing to a defect in the intestinal barrier structure (Muise et al., 2009). From a clinical point of view, increased intestinal permeability has been reported to predict an increased risk of relapse in CD patients on remission (Arnott et al., 2000; Tibble et al., 2000) and is considered as a risk factor for CD onset (Turpin et al., 2020). Serum proteins and antibodies related to immune responses to intestinal microbiota can predict the development of CD up to 5 years before the diagnosis (Torres et al., 2020). Therefore, leaky gut in patients with $\mathrm{CD}$ may allow the passage of intestinal microbes across the intestinal epithelium and drive local and systemic proinflammatory responses that worsens the prognosis in patients with $\mathrm{CD}$.

As a consequence of the impaired intestinal integrity, $C D$ patients need to respond to the frequent bacterial challenges to which they are exposed to and ensure the clearance of translocating bacteria. A competent intestinal antimicrobial peptide response is required to protect host from pathogens and to provide tolerance to normal flora (O'Neil et al., 1999; Ramasundara et al., 2009). Several studies have shown that Paneth cells in CD patients display alterations in the production and the activity of different antimicrobial peptides such as cathelicidin (Schauber et al., 2006; Tran et al., 2017), $\alpha$-defensins (Wehkamp et al., 2005; Elphick et al., 2008), and $\beta$-defensins (Kocsis et al., 2008; Schroeder et al., 2011), which are detrimental in the control of BT. Mutations in ATG16L1 and NOD2 in Paneth cells are associated with abnormalities in packaging and secretion of antimicrobials (Liu et al., 2014; VanDussen et al., 2014), therefore, affecting the antibacterial activity of the intestinal barrier by reduced secretion of mucosal $\alpha$-defensins observed in CD (Wehkamp et al., 2004, 2005; Kobayashi et al., 2005; Petnicki-Ocwieja et al., 2009). Intriguingly, serum levels of $\alpha$-defensins, but not $\beta$-defensins, are increased in patients with $\mathrm{CD}$ and they have been associated with serum C-reactive protein and TNF- $\alpha$ (Yamaguchi et al., 2009), while in healthy donors, peripheral $\alpha$-defensins remain constitutively expressed and $\beta$-defensins are induced by bacterial-derived products (Fang et al., 2003). We have demonstrated that bactDNA can modulate the expression of $\beta$-defensin (DEFB) 2 and cathelicidin LL37 through the mediation of NOD2 status by the signaling pathway of nuclear factor (NF)-ผB in CD (Gutiérrez et al., 2011). This evidence suggests that the NOD2 gene regulates signaling pathways linked to defensins and cathelicidins through the nuclear factor (NF)-к $\beta$ (Wehkamp et al., 2004; Voss et al., 2006). Consequently, patients with a NOD2 mutation have an increased likelihood of developing ileal $\mathrm{CD}$, and it is commonly accepted that an impaired NOD2 function can lead to a poor host clearance of bacteria, which can promote and perpetuate intestinal inflammation. A reduction in bacterial clearance has also been related to polymorphisms in ATG16L1 and IRGM genes, autophagy genes related to $\mathrm{CD}$ susceptibility (Hampe et al., 2007; Parkes et al., 2007; Rioux et al., 2007). A mutation on ATG16L1 and IRGM genes induces an injured autophagy pathway, resulting in a defective elimination of damaged cellular organelles and long-lived proteins as well as an altered degradation of intracellular bacteria.

Consequently, increased BT burden and altered microbial clearance in $\mathrm{CD}$ patients will induce sustained intestinal inflammatory responses that will be the topic addressed in the following section.

\section{INFLAMMATORY RESPONSE TO BACTERIAL TRANSLOCATION IN CROHN'S DISEASE}

The GI tract represents the largest surface area exposed to a wide and heterogeneous community of bacterial antigens. The gut is strictly regulated by innate and adaptive defense mechanisms, which altogether interact with commensal bacteria to promote the maintenance of intestinal homeostasis. Since CD is an immune-mediated condition triggered by environmental factors that imbalance the gut microbiota, perturb the intestinal barrier, and abnormally stimulate the gut immune response, an alteration in any of these compartments determines how the inflammatory immune response develops and may predispose to a disturbance of the bowel, leading to chronic inflammation. Here, we will describe in each one of the components involved in the process of BT and its role in the gut immune response and inflammation, which are summarized in Figure 1.

Intestinal barrier permeability increases the bacterial pressure to which the immune system needs to respond. When BT occurs, the first line of defense against microbial pathogens in the gut is composed of germline-coded pattern-recognition receptors (PRRs), which belong to the innate immune system (Medzhitov and Janeway, 2002). These receptors are located on both the extracellular or the intracellular side, and they recognize molecular patterns that are conserved in bacteria: pathogen-associated molecular patterns (PAMPs). PRRs are composed of transmembrane Toll-like receptors (TLRs), which have a key role in microbial recognition and induction of antimicrobial genes, and cytosolic NOD receptors whose main activity relies on bacterial clearance (Cario, 2005). Bacterial antigens such as endotoxin, forming complexes with LBP or DNA can sense and activate monocytes and macrophages via TLR receptors triggering the release of proinflammatory cytokines and chemokines TNF- $\alpha$, IL-6, IL-8, IL-21, or IFN- $\gamma$ through (NF)$\kappa \beta$ pathway (Hemmi et al., 2000; Wagner, 2002), similar to what MDP does via NOD2 (Lala et al., 2003; Eckmann and Karin, 2005) contributing to microbiota dysbiosis and tissue damage.

NLRs are important mediators in the control of intestinal inflammation, since the presence of gene polymorphisms in these molecules confers susceptibility to CD (Cummings et al., 2010). The activation of NLRs by PAMPs or danger-associated molecular patterns (DAMPs) result in downstream NF-kB signaling or caspase-1-mediated formation of inflammasomes (Rubino et al., 2012). NLRP3 inflammasome is activated in CD (Lazaridis et al., 2017), and its inhibition suppress the release of proinflammatory mediators (Liu et al., 2017). However, 


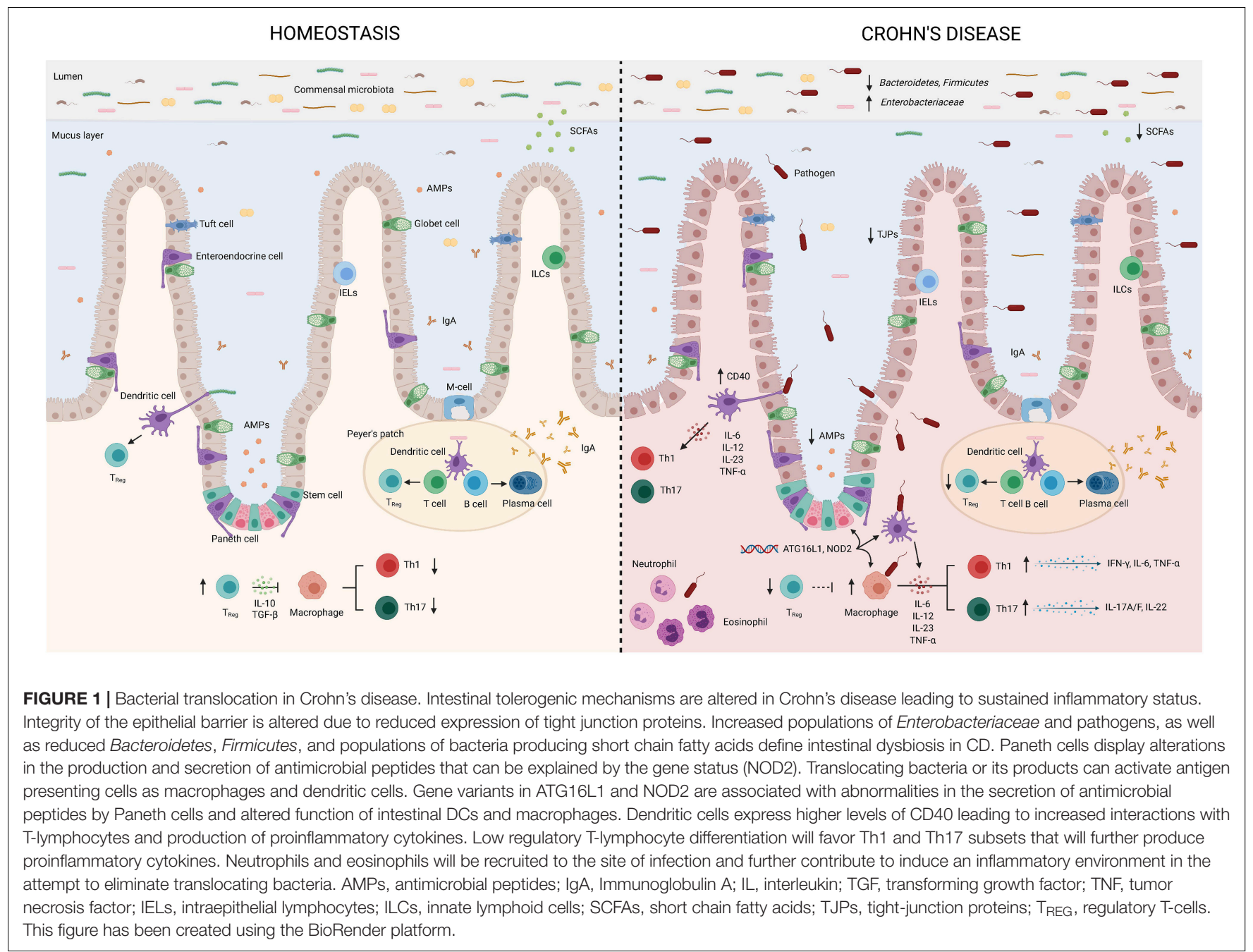

results from experimental models show controversial results since adverse and protective roles for NLRP3 have been reported. Attenuated colitis was described in both NLRP3-deficient mice (Bauer et al., 2012) and after selective blockade of NLRP3 (Perera et al., 2018) in different animal models of intestinal inflammation, whereas inflammatory progression associated with altered intestinal integrity and increased mortality have also been outlined in NLRP3 knockout mice with experimental colitis (Zaki et al., 2010). It seems that the contribution of NLRP3 to the pathogenesis of IBD is highly influenced by the environment, including intestinal microbiota, as this molecule not only controls potential invading pathogens (Song-Zhao et al., 2014) but also participates in an inflammatory lytic cell death of innate immune cells mediated by caspase-1, known as pyroptosis (Fink and Cookson, 2006). NLRC4 is another relevant member of the NLR family able to detect flagellin and components of the type III bacterial secretory apparatus. NLRC4 inflammasome expressed in intestinal phagocytes seems to become relevant in the discrimination of pathogen and commensal microbiota through the production of IL-1 $\beta$ (Franchi et al., 2012). Additionally, NLRC4-deficient mice were more susceptible to experimental colitis associated with increased mortality following flagellatedSalmonella infection (Carvalho et al., 2012). Recent studies demonstrated that NLRP6 inflammasome can be activated either by lipoteichoic acid from Listeria monocytogenes (Hara et al., 2018) or via interaction with LPS and ATP (Leng et al., 2020). NLRP6 not only becomes relevant in the host immune response to microbial infections through the production of IL18 but also mediates the secretion of mucins by globet cells (Wlodarska et al., 2014). Indeed, NLRP6-deficient mice showed more severe experimental colitis associated with a thinner mucus layer, susceptibility to bacterial infections, and altered intestinal microbiota (Elinav et al., 2011; Wlodarska et al., 2014). AIM2 belongs to the innate immune receptors sensing self or foreign cytosolic double-stranded DNA that results in the activation of caspase- 1 mediated by the AIM2 inflammasome and consequent release of processed IL-1 $\beta$ and IL-18 (Hornung et al., 2009). AIM2 protects against intestinal inflammation induced by experimental colitis by limiting the growth of E. coli and by affecting to the production of antimicrobial peptides (Hu et al., 2015).

In this first-line defense system, macrophages and dendritic cells (DC) play a key role. Alterations in these cell populations 
have been widely studied in the context of human IBD. Macrophages derived from the peripheral blood monocytes from CD patients showed impaired secretion of cytokines after E. coli insult and TLR ligation, contributing to a defective bacterial clearance (Smith et al., 2009). In addition, these cells showed an altered expression of surface markers, abundant secretion of IFN$\gamma$, IL-6, IL-23, and TNF- $\alpha$ (Kamada et al., 2008). TNF- $\alpha$ and IFN$\gamma$ are major contributors to intestinal permeability (Cao et al., 2013; Xu et al., 2019). Intestinal DC directly samples luminal bacteria and transfers bacterial antigens to the mesenteric lymph nodes and Peyer's patches to recruit neutrophils and eosinophils, and to modulate the subsequent T-cell responses (Rescigno et al., 2001; Hart et al., 2005).

Neutrophils recruited to the site of infection phagocyte and kill invading pathogens through reactive oxygen species (ROS) production, neutrophil extracellular traps (NETs), and generation of lytic proteins (Wéra et al., 2016). Neutrophils can also orchestrate local immune responses by releasing cytokines and chemokines such as IL-8, CXCL1, CCL3, CCL4, and CCL20 among others, that can interact and recruit leukocytes from innate and adaptative immune populations including other neutrophils, basophils, eosinophils, macrophages, monocytes, DCs, and T cells (Tecchio and Cassatella, 2016). The proper functioning of neutrophils is crucial to resolve the inflammation induced by translocating pathogens since the lack of function or an increased neutrophil activity may be the origin of intestinal inflammation. While accumulation of neutrophils in the lamina propria correlates with the activity of the disease in UC (Bressenot et al., 2015), several research lines report deficient neutrophil activity in CD. Some studies suggest that neutrophils from CD patients show impaired ROS generation (Hayee et al., 2011); however, it is not clear if there exists an intrinsic failure in neutrophils activity in $\mathrm{CD}$ or if this is due to defective macrophage signaling and consequent reduced neutrophil recruitment within the inflammatory area (Segal and Loewi, 1976). Reduced production of the neutrophil chemokine IL-8 support the abnormal neutrophil chemotaxis observed in inflammatory lesions during CD (Marks et al., 2006). The reduced activity of neutrophils against luminal microbes may partially explain the chronic local and systemic inflammation underlying CD induced by a permanent activation of macrophages and T cells (Segal, 2018). On the other hand, eosinophilia is present in CD mucosal biopsies, and it is specially abundant in mucosal nerves (Yantiss, 2015). Some clinical studies suggest peripheral blood eosinophilia as a marker of worse outcome in CD patients (Click et al., 2017).

Under physiological conditions, DC ensures homeostasis inducing a tolerogenic intestinal state (Kretschmer et al., 2005; Tsuji and Kosaka, 2008; Raker et al., 2015). However, the proinflammatory intestinal milieu in CD hinders the tolerogenic profile of these cells (Iliev et al., 2009). During inflammation, there is an increase in the number, maturation, and retention of DC, contributing to inflammation (Middel et al., 2006; Verstege et al., 2008). In CD, DC express higher levels of CD40 leading to increased interactions with T-lymphocytes and the production of great amounts of proinflammatory cytokines (Senhaji et al., 2015) such as IL-6 and IL-12, which are related to microbial changes (Ng et al., 2011) and dysregulation in T-cell apoptosis (Atreya et al., 2000) and, also, IL-8 and TNF- $\alpha$ (Baumgart et al., 2009). TNF- $\alpha$ is the key effector cytokine driving tissue injury during intestinal inflammation (Garrett et al., 2007); it can modulate intestinal mucus secretion and composition (McElroy et al., 2011) and the epithelial barrier function (Al-Sadi et al., 2016; Grabinger et al., 2017). In addition, NOD2 variants, which are most widely detected genetic risk variants associated with $\mathrm{CD}$ pathogenesis, disturb DC bacterial sensing, cytokine production, and antigen presentation pathways (Cooney et al., 2010).

Innate lymphoid cells (ILC) cells are also involved in the innate immune response in CD. Its biological relevance lies in their capacity to sense environmental signals and to respond with the secretion of cytokines, producing a profound impact on epithelial cells (Maloy and Powrie, 2011; Sonnenberg and Artis, 2012), and conditioning T-cell responses (von Burg et al., 2015). In CD patients, there is an expansion of an intraepithelial ILC1 subset that produces IFN- $\gamma$ in response to stimulation with IL-12 and IL-15 (Bernink et al., 2013; Fuchs et al., 2013), possible implication of ILC2 in the development of intestinal fibrosis through IL-13 secretion (Bailey et al., 2012), and ILC3 accumulation in inflamed areas, where they contribute to inflammation through increased IL-17 production and the recruitment of other immune cells (Geremia et al., 2011).

Mucosal $\mathrm{CD}^{+}{ }^{+} \mathrm{T}$-cells are central players in maintaining a proinflammatory cytokine response by pushing a predominantly T-helper type 1 (Th1)-mediated inflammatory state in environments where IL-12 is released by antigen-presenting cells (APCs). For many years, it was accepted that CD was mainly mediated by Th1 cells (Brand, 2009), based on the fact that an elevation of the Th1 cytokines was observed in CD patients (Fuss et al., 1996; Monteleone et al., 1997; Parronchi et al., 1997; Pizarro et al., 1999). However, further studies had led to the identification of another subset of $\mathrm{CD} 4^{+} \mathrm{T}$ characterized by the production of IL-17A, IL-17-F, and IL-22, which mediate T-helper type 17 (Th17) cells responses in CD (Strober and Fuss, 2011). An increase in Th17 cytokines produced by Th17 cells in inflamed gut mucosa (Fujino et al., 2003; Nielsen et al., 2003) as well as isolation and characterization of Th17 cells from gut mucosa of patients with CD (Annunziato et al., 2007) has supported the role of this cell population in IBD pathogenesis. CD displays a complex frame where Th1 and Th17 responses shift and depend on disease progression (Friedrich et al., 2019).

The differentiation of naïve $\mathrm{T}$ cells to Th17 cells is induced primarily by IL-6 and transforming growth factor (TGF)$\beta$ (Bettelli et al., 2006; Ivanov et al., 2006) and further reinforced by IL-1 $\beta$ and IL-23 (Langrish et al., 2005; Chung et al., 2009). IL-23 displays a central role in the maintenance and terminal commitment of naïve cells (Stritesky et al., 2008; McGeachy et al., 2009) and is implicated on the proliferation and expansion of Th17 cell populations (Veldhoen et al., 2006; Bettelli et al., 2007). IL-23R signaling in $\mathrm{T}$ cells drives the accumulation of intestinal Th17 cells while reducing the differentiation of tolerogenic FoxP3+ T-cells, as well as a reduced production of IL-10 by T-cells (Ahern et al., 2010). IL-23 induces T-cell expression of IL-17A, IL$17 \mathrm{~F}, \mathrm{TNF}-\alpha$, and granulocyte macrophage colony-stimulating 
factor (GM-CSF) (Langrish et al., 2005; Tait Wojno et al., 2019). Increased expression of IL-17A and IL-17F has been detected in the mucosa of patients with active CD (Fujino et al., 2003; Nielsen et al., 2003; Hölttä et al., 2008; Seiderer et al., 2008; Geremia et al., 2011). In addition, genome association analysis has revealed many IL-23R variants linked with CD (Cummings et al., 2007; Cotterill et al., 2010), and some IL-23R loss of function mutations are protective in both UC and CD (Kim et al., 2011). Therapies targeted to IL-23 and its signaling pathways are promising approaches in $\mathrm{CD}$ treatment as observed in other inflammatory disorders such as psoriasis or multiple sclerosis (Neurath, 2017; Visvanathan et al., 2018). Antibodies targeting the IL-23 signaling are classified in those recognizing the p40 subunit shared by IL12 and IL-23 or the p19 subunit unique in IL-23. Ustekinumab is an anti-p40 antibody with a favorable safety profile due to low rate of adverse events that shows a high rate of response and induce remission in moderate to severe $\mathrm{CD}$ patients (Feagan et al., 2016). Results from a phase 2 clinical trial in CD patients who failed in anti-TNF- $\alpha$ showed that selective IL-23 blockade using brazikumab, an anti-p19 antibody, was associated with clinical improvement at weeks 8 and 24, and higher serum levels of IL-22 (Sands et al., 2017). Similarly, another anti-IL23-specific antibody, risankizumab, induced clinical remission in CD patients with active disease at week 12 (Feagan et al., 2017). Biological treatments targeting the IL-17 signaling are effective in psoriasis (Langley et al., 2014). Nevertheless, antibody therapy against IL-17, secukinumab, and its receptor IL-17R, brodalumab, have demonstrated unexpected results in $\mathrm{CD}$, since two different clinical trials reported that the administration of secukinumab and brodalumab in moderate to severe $\mathrm{CD}$ patients were not effective and reported more adverse events and worsening of $\mathrm{CD}$ (Hueber et al., 2012; Targan et al., 2016).

IL-22 is another Th17-derived cytokine whose implication in IBD has been controversial. Some studies point to a protective role in the intestinal epithelium, stimulating the production of antimicrobial peptides (Okumura and Takeda, 2017), mucus secretion (Sugimoto et al., 2008), intestinal cell proliferation and survival (Zhang X. et al., 2019), and mucosal healing (Patnaude et al., 2021), while others mark that IL-22 may drive intestinal inflammation and gut epithelial cell death (Zha et al., 2019). These data suggest that its role during intestinal inflammation is highly context dependent. In fact, in the presence of eosinophilia, which is common during intestinal inflammation, IL-22 protective actions could be insufficient due to an increase in IL-22-binding protein (IL-22BP) (Martin et al., 2016).

Intensive research aiming to elucidate the contribution of Th17 responses to IBD have reported that IL-17 may exacerbate (Zhang et al., 2006) or protect (Yang et al., 2008; O'Connor et al., 2009) against intestinal inflammation depending on the experimental model studied. Results from Zhang and colleagues showed that IL-17R knockout mice presented reduced activity of experimental colitis induced by trinitrobenzenesulfonic (TNBS) acid. In line with this, the treatment with a soluble IL-17 receptor IgG fusion lessened intestinal inflammation induced by TNBS. On the other hand, studies conducted in animal models of colitis induced either by dextran sulfate sodium in IL-17 knockout mice or by CD45RB hi adoptive transfer using IL-17 or IL-17R-genetically deficient T-cells revealed an accelerated disease, therefore suggesting a protective role of IL-17 in those experimental systems. In order to determine the contribution of both Th1 and Th17 responses in CD, Sakuraba et al. isolated dendritic cells and lymphocytes from mesenteric lymph nodes of patients with $\mathrm{CD}$. The authors observed that isolated CD4+ T-cells were producing increased levels of IFN- $\gamma$ and IL-17, but isolated dendritic cells were activating CD4+T-lymphocytes toward the production of IFN- $\gamma$ (Sakuraba et al., 2009). Taken together, these evidences suggest that BT might contribute to modulate the inflammatory response in $\mathrm{CD}$ via enhancing a Th1/Th17 response associated with the presence of bacteria or their products, which perpetuates the progression of the disease in a subgroup of patients.

The intestinal Treg population is relevant in the inflammatory responses to $\mathrm{BT}$ in $\mathrm{CD}$, as they oversee tissue repair and immunological tolerance toward food antigens and microbiota in the gut, contributing to intestinal homeostasis (Kim et al., 2016; Tanoue et al., 2016; Xu et al., 2018). They belong to CD4+ lymphocytes and can suppress the immune response interacting with different components of the innate and adaptive immune response. Treg cells are highly heterogenous and express different lineage-specific transcription factors and cellular markers in different scenarios (Zhang et al., 2020). Treg cell populations produce IL-10 and TGF- $\beta$, and they can be naturally synthesized through thymic selection or induced after antigenic stimulation outside the thymus (Roncarolo et al., 2006; Sakaguchi et al., 2010), also in the gut by mucosal $\mathrm{CD}_{103^{+}}$dendritic cells via a TGF- $\beta$ and retinoic acid-dependent mechanism (Coombes et al., 2007). Treg secretion of IL-10 is important to control the gut balance. In fact, intestinal Th1-mediated inflammatory responses result in spontaneous colitis in IL-10-deficient mice (Davidson et al., 1996), and polymorphisms in the human IL-10R result in exacerbated intestinal immune responses (Glocker et al., 2009).

Changes in the percentage of Treg cells in patients with IBD have been reported (Maul et al., 2005), and a decreased number of CD4+ CD25+ FoxP3+ Treg cells have been observed in the lamina propria of patients with CD-related NOD2 variants (Rahman et al., 2010). Also, mutations in FOXP3 gene are related to the development of IBD (Okou et al., 2014). In the inflammatory milieu of $\mathrm{CD}$, some groups have reported an enhanced recruitment of Treg cells in mucosal areas, suggesting a deficient suppressive activity during inflammation (Chamouard et al., 2009). These could be explained through changes in its cytokine profile similar to Th17 cells in the context of IBD (Hovhannisyan et al., 2011; Ueno et al., 2013) and also a diminished expression of transcription factors involved in Treg regulation in CD (Qiao et al., 2013). On the other hand, recently, a subset of Treg CD161+ cells has been found highly enriched in the mucosa of $\mathrm{CD}$ patients, which are involved in wound healing and associated with reduced inflammation (Povoleri et al., 2018). All of these suggest that different Treg subsets could behave differentially in IBD. Due to its immunomodulatory capacity, therapies targeting this cell population are being assessed with promising results (Desreumaux et al., 2012; Trotta et al., 2018; Clough et al., 2020).

The microbiome is key in the equilibrium between Treg and Th17 in the gut (Lochner et al., 2011; Ohnmacht et al., 2015; 
Sefik et al., 2015). Microbiota from IBD donors into germfree mice reduced the presence of $\operatorname{ROR} \gamma \mathrm{t}+$ Treg cells but increased Th17 and Th2 populations (Britton et al., 2019). On the other hand, commensal microbiota can promote CD4+ CD25+ FoxP3+ Treg cells in vivo, which control the innate inflammatory cascade to translocating microbes by reducing proinflammatory cytokine production, reducing $\mathrm{T}$-cell proliferation, reducing dendritic cell co-stimulatory molecule expression, and attenuating (NF)-к $\beta$ activation (O'Mahony et al., 2008). SCFAs produced by Bifidobacteria and Clostridia, like butyrate, cause inhibition of histone deacetylase (HDAC), promoting FoxP3 expression (Arpaia et al., 2013) and production of retinoic acid (Smith et al., 2013; Schilderink et al., 2016) polysaccharide A of Bacteroides fragilis induces an intestinal tolerogenic environment by promoting the IL-10producing Foxp3+ Treg population (Round and Mazmanian, 2010), and indole-3-aldehyde, produced by Lactobacillus reuteri, is a tryptophan precursor involved in the plasticity of $\mathrm{T}$ cells (Lamas et al., 2016). In addition, Clostridiodes spp. mixture transplantation is also associated with increased counts of intestinal Treg cells in mice (Atarashi et al., 2013; Narushima et al., 2014).

\section{EFFICACY OF ANTI-TNF- $\alpha$ TREATMENT IN PATIENTS WITH BACTERIAL TRANSLOCATION}

Biologic treatments including anti-TNF- $\alpha$, adhesion molecule inhibitors, and p-40 IL-12/23 inhibitor, ustekinumab, are effective therapies for patients with moderate to severe IBD (Katsanos et al., 2019). Anti-TNF- $\alpha$ monoclonal antibodies were the first biologic agents that demonstrated effectiveness in the treatment of CD (Rutgeerts et al., 1999; Hanauer et al., 2002; Sands et al., 2004; Xiao et al., 2016) as TNF- $\alpha$ is increased in the intestinal mucosa of IBD patients (Breese et al., 1994; Dionne et al., 1997). Increased intestinal TNF- $\alpha$ could be directly involved in BT, as it can disrupt intestinal epithelial integrity (Al-Sadi et al., 2016; Grabinger et al., 2017) and mediate tissue injury (Garrett et al., 2007). However, it is known that $30-40 \%$ of patients with IBD under anti-TNF therapy show a primary non-response, and up to $50 \%$ may present adverse events or develop secondary nonresponse over time (Ben-Horin and Chowers, 2011; Papamichael et al., 2017). Focusing on the efficacy of anti-TNF- $\alpha$ therapy, further research has also found that undetectable serum through concentration of anti-TNF- $\alpha$ levels (Maser et al., 2006) and decreased free TNF- $\alpha$ binding capacity of anti-TNF- $\alpha$ drugs (Ainsworth et al., 2008) are predictors of poor response to antiTNF- $\alpha$ treatment of patients with CD. Even if serum levels of TNF- $\alpha$ have also been proposed to predict the efficacy of antiTNF- $\alpha$ in CD patients (Martínez-Borra et al., 2002), several studies have reported that serum TNF- $\alpha$ is not a good predictor of clinical response to anti-TNF- $\alpha$ therapy (Ogawa et al., 2012). Besides clinical factors and the development of antibodies against anti-TNF- $\alpha$ agents (Baert et al., 2003), several other factors such as BT and a susceptible genotype, intestinal dysbiosis, and even the Treg population may have a role in this loss of response.
In the past, we investigated the effects of different gene variants and BT in the efficacy of anti-TNF- $\alpha$ therapy in CD. We identified a subgroup of $\mathrm{CD}$ patients characterized by the presence of a variant NOD2 genotype, in combination or not with a variant ATG16L1 genotype, who may need an intensified anti-TNF- $\alpha$ drug schedule since they showed increased bactDNA translocation, augmented inflammatory response, and increased risk of relapse. In detail, the presence of a variant NOD2 genotype, either alone or combined with ATG16L1 variant genotype, was associated with increased bactDNA translocation, and the presence of serum bactDNA was associated with relapse at 6 months. Patients with bactDNA showed increased proinflammatory cytokines response that was further augmented in patients who were also carrying combined NOD2/ATG16L1 variants. A variant NOD2 genotype correlated with reduced phagocytic and bactericidal activities in neutrophils and exacerbated in vitro TNF- $\alpha$ secretion in response to $E$. coli, suggesting that neutrophils from CD patients carrying a variant NOD2 genotype have altered bacterial clearance. Evaluation on anti-TNF- $\alpha$ therapy on patients carrying NOD2/ATG16L1 combined genotypes revealed that most of these patients were on an intensified anti-TNF- $\alpha$ drug schedule. Moreover, free antiTNF- $\alpha$ levels were significantly decreased in the serum of patients with bactDNA translocation and a variant NOD2 genotype and, especially, in patients with a combined NOD2/ATG16L1 variant, suggesting that increased drug consumption is necessary on these patients to promote an adequate tolerogenic response (Gutiérrez et al., 2014). We further demonstrated that the presence of bactDNA in CD patients is a significant independent risk factor of short-term relapse in those in remission, especially in the ones with mucosal lesions, suggesting that the presence of mucosal damage is not essential for BT, but it contributes to it, in synergy with bactDNA (Gutiérrez et al., 2016). In line with this, we observed that the increase in bactDNA and TNF- $\alpha$ in CD patients could be related with a variant in IL-26 gene. This variant was associated with an impaired antibacterial clearance, increased inflammatory cytokines, and an increment in antiTNF- $\alpha$ consumption in CD patients (Piñero et al., 2017). This also contributes to explain why SNPs in IL-26 gene confer genetic susceptibility to CD (Silverberg et al., 2009). All these findings suggest that BT aggravates the inflammatory response and predisposes to risk of relapse and need of intensified antiTNF- $\alpha$ drug therapies in susceptible CD patients.

It is well-known that levels of anti-TNF- $\alpha$ determine the treatment response (Moore et al., 2016), but recent studies manifest that intestinal dysbiosis might also play a role in the efficacy of the biologic therapy. Therefore, initial gut microbial composition and cytokine profile before anti-TNF- $\alpha$ therapy, as well as anti-TNF- $\alpha$-induced microbial changes during the treatment are key in the achievement of clinical remission (Jones-Hall and Nakatsu, 2016; Franzin et al., 2021) and IBD patients with greater gut dysbiosis achieve clinical remission later (Aden et al., 2019). The treatment with anti-TNF- $\alpha$ improves the intestinal dysbiosis in CD by increasing SCFAs producing bacteria like Anaerostipes, Blautia, Coprococcus, Faecalibacterium, Lachnospira, and Roseburia (Kowalska-Duplaga et al., 2020; 
Seong et al., 2020) and decreasing bacterial species associated with mucosal damage (Busquets et al., 2015; Ribaldone et al., 2019). The relevance of intestinal microbiota in the efficacy of current IBD treatments is certainly an open research field that deserves more in-depth investigations.

Finally, the Treg population has been shown to actively participate in the loss of response to anti-TNF- $\alpha$. An increased peripheral blood Treg cell population after anti-TNF- $\alpha$ therapy administration is related with increased serum levels of TGF$\beta$ and IL-10 and with the clinical improvement observed in patients with CD (Di Sabatino et al., 2010; Guidi et al., 2013). Indeed, we have also reported that Treg population is susceptible to significantly increase after anti-TNF- $\alpha$ administration in CD patients bearing a wild-type NOD2 genotype. Nevertheless, CD patients carrying a polymorphism in NOD2 have lower available serum levels of anti-TNF- $\alpha$ and an impaired capacity to induce the Treg population. Altogether, these results suggest an impaired immunological function in this subgroup of CD patients, as demonstrated by increased serum levels of TNF- $\alpha$. Accordingly, most of these patients were on anti-TNF- $\alpha$ intensified therapy and showed a more aggressive CD phenotype. Furthermore, we found that $\mathrm{CD}$ patients showing perianal lesions had lower circulating Treg population. Thus, immunophenotyping Treg cells in blood of patients with $\mathrm{CD}$ can be a fast and helpful methodology to anticipate not only the clinical response to biological therapy but also a more aggressive phenotype of $\mathrm{CD}$ (Juanola et al., 2014).

\section{FUTURE DIRECTIONS}

To predict $\mathrm{CD}$ behavior is a topic of strong interest that would greatly improve the welfare of patients. The multifactorial etiology of the disease makes it necessary to consider several aspects from genetic to environmental factors in an attempt to determine the risk of relapse (Timmer et al., 1998; Tibble et al.,

\section{REFERENCES}

Aden, K., Rehman, A., Waschina, S., Pan, W. H., Walker, A., Lucio, M., et al. (2019). Metabolic Functions of Gut Microbes Associate With Efficacy of Tumor Necrosis Factor Antagonists in Patients With Inflammatory Bowel Diseases. Gastroenterology 157, 1279-1292.e11.

Ahern, P. P., Schiering, C., Buonocore, S., McGeachy, M. J., Cua, D. J., Maloy, K. J., et al. (2010). Interleukin-23 drives intestinal inflammation through direct activity on T cells. Immunity 33, 279-288. doi: 10.1016/j.immuni.2010.08.010

Ainsworth, M. A., Bendtzen, K., and Brynskov, J. (2008). Tumor necrosis factoralpha binding capacity and anti-infliximab antibodies measured by fluid-phase radioimmunoassays as predictors of clinical efficacy of infliximab in Crohn's disease. Am. J. Gastroenterol. 103, 944-948. doi: 10.1111/j.1572-0241.2007. 01638.x

Alexander, J. W., Boyce, S. T., Babcock, G. F., Gianotti, L., Peck, M. D., Dunn, D. L., et al. (1990). The process of microbial translocation. Ann. Surg. 212, 496-510; discussion1-2.

Al-Sadi, R., Guo, S., Ye, D., Rawat, M., and Ma, T. Y. (2016). TNF- $\alpha$ modulation of intestinal tight junction permeability is mediated by NIK/IKK- $\alpha$ axis activation of the canonical NF-кB pathway. Am. J. Pathol. 186, 1151-1165. doi: 10.1016/j. ajpath.2015.12.016

Annunziato, F., Cosmi, L., Santarlasci, V., Maggi, L., Liotta, F., Mazzinghi, B., et al. (2007). Phenotypic and functional features of human Th17 cells. J. Exp. Med. 204, 1849-1861. doi: 10.1084/jem.20070663
2000; Beaugerie et al., 2006; Takeuchi et al., 2006). However, the clinical value, so far, is limited due to lack of specificity.

As shown in this review, many lines of evidence point to the translocation of bacterial products as an important player leading to uncontrolled inflammation in CD patients. Even if the question still arises about BT as the cause or the consequence of intestinal inflammation, it is widely accepted that host-bacterial interactions influence CD. Therefore, evaluating the presence of gut bacterial antigens at a systemic level may constitute a new marker for increased risk of relapse among CD patients. Of particular interest is the combination of BT and CD-related susceptibility genes such as NOD2, which probably facilitates the translocation of bacterial antigens; this is worth exploring in the context of response to TNF- $\alpha$ antagonists and risk of relapse.

Further studies aimed at understanding the interaction between the immune system, both at systemic and mucosal level, gut microbiota, and genetic predisposition will help clinicians to better control and individually treat CD patients in the future.

\section{AUTHOR CONTRIBUTIONS}

All authors listed have made a substantial, direct and intellectual contribution to the work, and approved it for publication.

\section{FUNDING}

$\mathrm{RL}$ is a recipient of an FPU grant, Ministerio Innovación, Ciencia y Universidad, Gobierno de España, and OJ received a postdoctoral fellowship from Asociación Española para el Estudio del Hígado. This work has been partially funded by Instituto ISABIAL, Hospital General Universitario de Alicante, Spain (UGP-2020-0287), and by Instituto de Salud Carlos III, Madrid, Spain (PI21/01702).

Arnott, I. D., Kingstone, K., and Ghosh, S. (2000). Abnormal intestinal permeability predicts relapse in inactive Crohn disease. Scand. J. Gastroenterol. 35, 11631169. doi: 10.1080/003655200750056637

Arpaia, N., Campbell, C., Fan, X., Dikiy, S., van der Veeken, J., deRoos, P., et al. (2013). Metabolites produced by commensal bacteria promote peripheral regulatory T-cell generation. Nature 504, 451-455. doi: 10.1038/nature12726

Atarashi, K., Tanoue, T., Oshima, K., Suda, W., Nagano, Y., Nishikawa, H., et al. (2013). Treg induction by a rationally selected mixture of Clostridia strains from the human microbiota. Nature 500, 232-236. doi: 10.1038/nature1 2331

Atreya, R., Mudter, J., Finotto, S., Müllberg, J., Jostock, T., Wirtz, S., et al. (2000). Blockade of interleukin 6 trans signaling suppresses T-cell resistance against apoptosis in chronic intestinal inflammation: evidence in crohn disease and experimental colitis in vivo. Nat. Med. 6, 583-588. doi: 10.1038/75068

Baert, F., Noman, M., Vermeire, S., Van Assche, G., D’ Haens, G., Carbonez, A., et al. (2003). Influence of immunogenicity on the long-term efficacy of infliximab in disease. N. Engl. J. Med. 348, 601-608. doi: 10.1056/nejmoa02 0888

Bailey, J. R., Bland, P. W., Tarlton, J. F., Peters, I., Moorghen, M., Sylvester, P. A., et al. (2012). IL-13 promotes collagen accumulation in Crohn's disease fibrosis by down-regulation of fibroblast MMP synthesis: a role for innate lymphoid cells? PLoS One 7:e52332. doi: 10.1371/journal.pone.0052332

Bauer, C., Duewell, P., Lehr, H. A., Endres, S., and Schnurr, M. (2012). Protective and aggravating effects of Nlrp3 inflammasome activation in IBD models: 
influence of genetic and environmental factors. Dig. Dis. 30(Suppl. 1), 82-90. doi: $10.1159 / 000341681$

Baumgart, D. C., Thomas, S., Przesdzing, I., Metzke, D., Bielecki, C., Lehmann, S. M., et al. (2009). Exaggerated inflammatory response of primary human myeloid dendritic cells to lipopolysaccharide in patients with inflammatory bowel disease. Clin. Exp. Immunol. 157, 423-436. doi: 10.1111/j.1365-2249. 2009.03981.x

Beaugerie, L., Seksik, P., Nion-Larmurier, I., Gendre, J. P., and Cosnes, J. (2006). Predictors of Crohn's disease. Gastroenterology 130, 650-656.

Ben-Horin, S., and Chowers, Y. (2011). Review article: loss of response to antiTNF treatments in Crohn's disease. Aliment Pharmacol. Ther. 33, 987-995. doi: 10.1111/j.1365-2036.2011.04612.x

Bernink, J. H., Peters, C. P., Munneke, M., te Velde, A. A., Meijer, S. L., Weijer, K., et al. (2013). Human type 1 innate lymphoid cells accumulate in inflamed mucosal tissues. Nat. Immunol. 14, 221-229. doi: 10.1038/ni.2534

Bettelli, E., Carrier, Y., Gao, W., Korn, T., Strom, T. B., Oukka, M., et al. (2006). Reciprocal developmental pathways for the generation of pathogenic effector TH17 and regulatory T cells. Nature 441, 235-238. doi: 10.1038/nature0 4753

Bettelli, E., Oukka, M., and Kuchroo, V. K. T. (2007). (H)-17 cells in the circle of immunity and autoimmunity. Nat. Immunol. 8, 345-350. doi: 10.1038/ni0407345

Brand, S. (2009). Crohn's disease: Th1, Th17 or both? The change of a paradigm: new immunological and genetic insights implicate Th17 cells in the pathogenesis of Crohn's disease. Gut 58, 1152-1167. doi: 10.1136/gut.2008. 163667

Breese, E. J., Michie, C. A., Nicholls, S. W., Murch, S. H., Williams, C. B., Domizio, P., et al. (1994). Tumor necrosis factor alpha-producing cells in the intestinal mucosa of children with inflammatory bowel disease. Gastroenterology 106, 1455-1466. doi: 10.1016/0016-5085(94)90398-0

Bressenot, A., Salleron, J., Bastien, C., Danese, S., Boulagnon-Rombi, C., and Peyrin-Biroulet, L. (2015). Comparing histological activity indexes in UC. Gut 64, 1412-1418. doi: 10.1136/gutjnl-2014-307477

Britton, G. J., Contijoch, E. J., Mogno, I., Vennaro, O. H., Llewellyn, S. R., Ng, R., et al. (2019). Microbiotas from humans with inflammatory bowel disease alter the balance of gut Th17 and ROR $\gamma$ t. Immunity 50, 212-224.e4.

Britton, G. J., Contijoch, E. J., Spindler, M. P., Aggarwala, V., Dogan, B., Bongers, G., et al. (2020). Defined microbiota transplant restores Th17/ROR $\gamma$ t. Proc. Natl. Acad. Sci. U.S.A. 117, 21536-21545. doi: 10.1073/pnas.1922189117

Buhner, S., Buning, C., Genschel, J., Kling, K., Herrmann, D., Dignass, A., et al. (2006). Genetic basis for increased intestinal permeability in families with Crohn's disease: role of CARD15 3020insC mutation? Gut 55, 342-347. doi: 10.1136/gut.2005.065557

Buisine, M. P., Desreumaux, P., Debailleul, V., Gambiez, L., Geboes, K., Ectors, N., et al. (1999). Abnormalities in mucin gene expression in Crohn's disease. Inflamm. Bowel. Dis. 5, 24-32. doi: 10.1002/ibd.3780050105

Busquets, D., Mas-de-Xaxars, T., López-Siles, M., Martínez-Medina, M., Bahí, A., Sàbat, M., et al. (2015). Anti-tumour necrosis factor treatment with adalimumab induces changes in the microbiota of Crohns disease. J. Crohns Colitis 9, 899-906. doi: 10.1093/ecco-jcc/jjv119

Cadwell, K., Patel, K. K., Maloney, N. S., Liu, T. C., Ng, A. C., Storer, C. E., et al. (2010). Virus-plus-susceptibility gene interaction determines Crohn's disease gene Atg16L1 phenotypes in intestine. Cell 141, 1135-1145. doi: 10.1016/j.cell. 2010.05.009

Cao, M., Wang, P., Sun, C., He, W., and Wang, F. (2013). Amelioration of IFN$\gamma$ and TNF- $\alpha$-induced intestinal epithelial barrier dysfunction by berberine via suppression of MLCK-MLC phosphorylation signaling pathway. PLoS One 8:e61944. doi: 10.1371/journal.pone.0061944

Cario, E. (2005). Bacterial interactions with cells of the intestinal mucosa: Toll-like receptors and NOD2. Gut 54, 1182-1193. doi: 10.1136/gut.2004.062794

Carvalho, F. A., Nalbantoglu, I., Aitken, J. D., Uchiyama, R., Su, Y., Doho, G. H., et al. (2012). Cytosolic flagellin receptor NLRC4 protects mice against mucosal and systemic challenges. Mucosal. Immunol. 5, 288-298. doi: 10.1038/mi. 2012.8

Castiglione, F., Rispo, A., Di Girolamo, E., Cozzolino, A., Manguso, F., Grassia, R., et al. (2003). Antibiotic treatment of small bowel bacterial overgrowth in patients with Crohn's disease. Aliment Pharmacol. Ther. 18, 1107-1112. doi: 10.1046/j.1365-2036.2003.01800.x
Chamouard, P., Monneaux, F., Richert, Z., Voegeli, A. C., Lavaux, T., Gaub, M. P., et al. (2009). Diminution of circulating CD4+CD25 high T cells in naïve Crohn's disease. Dig. Dis. Sci. 54, 2084-2093.

Chang, J. T. (2020). Pathophysiology of inflammatory bowel diseases. N. Engl. J. Med. 383, 2652-2664.

Chassaing, B., and Darfeuille-Michaud, A. (2011). The commensal microbiota and enteropathogens in the pathogenesis of inflammatory bowel diseases. Gastroenterology 140, 1720-1728. doi: 10.1053/j.gastro.2011.01.054

Chung, Y., Chang, S. H., Martinez, G. J., Yang, X. O., Nurieva, R., Kang, H. S., et al. (2009). Critical regulation of early Th17 cell differentiation by interleukin-1 signaling. Immunity 30, 576-587. doi: 10.1016/j.immuni.2009.02.007

Click, B., Anderson, A. M., Koutroubakis, I. E., Rivers, C. R., Babichenko, D., Machicado, J. D., et al. (2017). Peripheral eosinophilia in patients with inflammatory bowel disease defines an aggressive disease phenotype. Am. J. Gastroenterol. 112, 1849-1858. doi: 10.1038/ajg.2017.402

Clough, J. N., Omer, O. S., Tasker, S., Lord, G. M., and Irving, P. M. (2020). Regulatory T-cell therapy in Crohn's disease: challenges and advances. Gut 69, 942-952. doi: 10.1136/gutjnl-2019-319850

Coombes, J. L., Siddiqui, K. R., Arancibia-Cárcamo, C. V., Hall, J., Sun, C. M., Belkaid, Y., et al. (2007). A functionally specialized population of mucosal CD103+ DCs induces Foxp3+ regulatory T cells via a TGF-beta and retinoic acid-dependent mechanism. J. Exp. Med. 204, 1757-1764. doi: 10.1084/jem. 20070590

Cooney, R., Baker, J., Brain, O., Danis, B., Pichulik, T., Allan, P., et al. (2010). NOD2 stimulation induces autophagy in dendritic cells influencing bacterial handling and antigen presentation. Nat. Med. 16, 90-97. doi: 10.1038/nm.2069

Cotterill, L., Payne, D., Levinson, S., McLaughlin, J., Wesley, E., Feeney, M., et al. (2010). Replication and meta-analysis of 13,000 cases defines the risk for interleukin-23 receptor and autophagy-related 16-like 1 variants in Crohn's disease. Can. J. Gastroenterol. 24, 297-302. doi: 10.1155/2010/48 0458

Craven, M., Egan, C. E., Dowd, S. E., McDonough, S. P., Dogan, B., Denkers, E. Y., et al. (2012). Inflammation drives dysbiosis and bacterial invasion in murine models of ileal Crohn's disease. PLoS One 7:e41594. doi: 10.1371/journal.pone. 0041594

Cummings, J. R., Ahmad, T., Geremia, A., Beckly, J., Cooney, R., Hancock, L., et al. (2007). Contribution of the novel inflammatory bowel disease gene IL23R to disease susceptibility and phenotype. Inflamm. Bowel. Dis. 13, 1063-1068. doi: 10.1002/ibd.20180

Cummings, J. R., Cooney, R. M., Clarke, G., Beckly, J., Geremia, A., Pathan, S., et al. (2010). The genetics of NOD-like receptors in Crohn's disease. Tissue Antigens 76, 48-56.

D’Aoust, J., Battat, R., and Bessissow, T. (2017). Management of inflammatory bowel disease with. World J. Gastroenterol. 23, 4986-5003.

Darfeuille-Michaud, A., Boudeau, J., Bulois, P., Neut, C., Glasser, A. L., Barnich, N., et al. (2004). High prevalence of adherent-invasive Escherichia coli associated with ileal mucosa in Crohn's disease. Gastroenterology 127, 412-421. doi: $10.1053 /$ j.gastro.2004.04.061

Davidson, N. J., Leach, M. W., Fort, M. M., Thompson-Snipes, L., Kühn, R., Müller, W., et al. (1996). T helper cell 1-type CD4+ T cells, but not B cells, mediate colitis in interleukin 10-deficient mice. J. Exp. Med. 184, 241-251. doi: 10.1084/jem.184.1.241

Desreumaux, P., Foussat, A., Allez, M., Beaugerie, L., Hébuterne, X., Bouhnik, Y., et al. (2012). Safety and efficacy of antigen-specific regulatory T-cell therapy for patients with refractory Crohn's disease. Gastroenterology 143, 1207-1217.e1-2.

Di Sabatino, A., Biancheri, P., Piconese, S., Rosado, M. M., Ardizzone, S., Rovedatti, L., et al. (2010). Peripheral regulatory T cells and serum transforming growth factor-beta: relationship with clinical response to infliximab in Crohn's disease. Inflamm. Bowel. Dis. 16, 1891-1897. doi: 10.1002/ibd.2 1271

Dionne, S., Hiscott, J., D’Agata, I., Duhaime, A., and Seidman, E. G. (1997). Quantitative PCR analysis of TNF-alpha and IL-1 beta mRNA levels in pediatric IBD mucosal biopsies. Dig. Dis. Sci. 42, 1557-1566.

Eckburg, P. B., Bik, E. M., Bernstein, C. N., Purdom, E., Dethlefsen, L., Sargent, M., et al. (2005). Diversity of the human intestinal microbial flora. Science 308, 1635-1638. doi: 10.1126/science.1110591

Eckmann, L., and Karin, M. (2005). NOD2 and Crohn's disease: loss or gain of function? Immunity 22, 661-667. doi: 10.1016/j.immuni.2005.06.004 
Elinav, E., Strowig, T., Kau, A. L., Henao-Mejia, J., Thaiss, C. A., Booth, C. J., et al. (2011). NLRP6 inflammasome regulates colonic microbial ecology and risk for colitis. Cell 145, 745-757. doi: 10.1016/j.cell.2011.04.022

Elphick, D., Liddell, S., and Mahida, Y. R. (2008). Impaired luminal processing of human defensin-5 in Crohn's disease: persistence in a complex with chymotrypsinogen and trypsin. Am. J. Pathol. 172, 702-713. doi: 10.2353/ ajpath.2008.070755

Elson, C. O., Cong, Y., McCracken, V. J., Dimmitt, R. A., Lorenz, R. G., and Weaver, C. T. (2005). Experimental models of inflammatory bowel disease reveal innate, adaptive, and regulatory mechanisms of host dialogue with the microbiota. Immunol. Rev. 206, 260-276. doi: 10.1111/j.0105-2896.2005.00291.X

Fang, X. M., Shu, Q., Chen, Q. X., Book, M., Sahl, H. G., Hoeft, A., et al. (2003). Differential expression of alpha- and beta-defensins in human peripheral blood. Eur. J. Clin. Invest. 33, 82-87. doi: 10.1046/j.1365-2362.2003.01076.x

Feagan, B. G., Sandborn, W. J., D’Haens, G., Panés, J., Kaser, A., Ferrante, M., et al. (2017). Induction therapy with the selective interleukin-23 inhibitor risankizumab in patients with moderate-to-severe Crohn's disease: a randomised, double-blind, placebo-controlled phase 2 study. Lancet 389, 1699-1709. doi: 10.1016/s0140-6736(17)30570-6

Feagan, B. G., Sandborn, W. J., Gasink, C., Jacobstein, D., Lang, Y., Friedman, J. R., et al. (2016). Ustekinumab as induction and maintenance therapy for Crohn's disease. N. Engl. J. Med. 375, 1946-1960.

Fink, S. L., and Cookson, B. T. (2006). Caspase-1-dependent pore formation during pyroptosis leads to osmotic lysis of infected host macrophages. Cell Microbiol. 8, 1812-1825. doi: 10.1111/j.1462-5822.2006.00751.x

Forbes, J. D., Van Domselaar, G., and Bernstein, C. N. (2016). Microbiome survey of the inflamed and noninflamed gut at different compartments within the gastrointestinal tract of inflammatory bowel disease patients. Inflamm. Bowel. Dis. 22, 817-825. doi: 10.1097/mib.0000000000000684

Franchi, L., Kamada, N., Nakamura, Y., Burberry, A., Kuffa, P., Suzuki, S., et al. (2012). NLRC4-driven production of IL-1 $\beta$ discriminates between pathogenic and commensal bacteria and promotes host intestinal defense. Nat. Immunol. 13, 449-456. doi: 10.1038/ni.2263

Frank, D. N., St Amand, A. L., Feldman, R. A., Boedeker, E. C., Harpaz, N., and Pace, N. R. (2007). Molecular-phylogenetic characterization of microbial community imbalances in human inflammatory bowel diseases. Proc. Natl. Acad. Sci. U.S.A. 104, 13780-13785. doi: 10.1073/pnas.0706625104

Franke, A., McGovern, D. P., Barrett, J. C., Wang, K., Radford-Smith, G. L., Ahmad, T., et al. (2010). Genome-wide meta-analysis increases to 71 the number of confirmed Crohn's disease susceptibility loci. Nat. Genet 42, 1118-1125.

Franzin, M., Stefančič, K., Lucafò, M., Decorti, G., and Stocco, G. (2021). Microbiota and drug response in inflammatory bowel disease. Pathogens 10:211. doi: 10.3390/pathogens10020211

Franzosa, E. A., Sirota-Madi, A., Avila-Pacheco, J., Fornelos, N., Haiser, H. J., Reinker, S., et al. (2019). Gut microbiome structure and metabolic activity in inflammatory bowel disease. Nat. Microbiol. 4, 293-305.

Friedrich, M., Pohin, M., and Powrie, F. (2019). Cytokine networks in the pathophysiology of inflammatory bowel disease. Immunity 50, 992-1006. doi: 10.1016/j.immuni.2019.03.017

Fuchs, A., Vermi, W., Lee, J. S., Lonardi, S., Gilfillan, S., Newberry, R. D., et al. (2013). Intraepithelial type 1 innate lymphoid cells are a unique subset of IL12- and IL-15-responsive IFN- $\gamma$-producing cells. Immunity 38, 769-781. doi: 10.1016/j.immuni.2013.02.010

Fujino, S., Andoh, A., Bamba, S., Ogawa, A., Hata, K., Araki, Y., et al. (2003). Increased expression of interleukin 17 in inflammatory bowel disease. Gut 52, 65-70. doi: 10.1136/gut.52.1.65

Fuss, I. J., Neurath, M., Boirivant, M., Klein, J. S., de la Motte, C., Strong, S. A., et al. (1996). Disparate CD4+ lamina propria (LP) lymphokine secretion profiles in inflammatory bowel disease. Crohn's disease LP cells manifest increased secretion of IFN-gamma, whereas ulcerative colitis LP cells manifest increased secretion of IL-5. J. Immunol. 157, 1261-1270.

Garrett, W. S., Lord, G. M., Punit, S., Lugo-Villarino, G., Mazmanian, S. K., Ito, S., et al. (2007). Communicable ulcerative colitis induced by T-bet deficiency in the innate immune system. Cell 131, 33-45. doi: 10.1016/j.cell.2007.08.017

Geremia, A., Arancibia-Cárcamo, C. V., Fleming, M. P., Rust, N., Singh, B., Mortensen, N. J., et al. (2011). IL-23-responsive innate lymphoid cells are increased in inflammatory bowel disease. J. Exp. Med. 208, 1127-1133. doi: $10.1084 /$ jem.20101712
Gevers, D., Kugathasan, S., Denson, L. A., Vázquez-Baeza, Y., Van Treuren, W., Ren, B., et al. (2014). The treatment-naive microbiome in new-onset Crohn's disease. Cell Host Microbe 15, 382-392.

Gill, S. R., Pop, M., Deboy, R. T., Eckburg, P. B., Turnbaugh, P. J., Samuel, B. S., et al. (2006). Metagenomic analysis of the human distal gut microbiome. Science 312, 1355-1359.

Glocker, E. O., Kotlarz, D., Boztug, K., Gertz, E. M., Schäffer, A. A., Noyan, F., et al. (2009). Inflammatory bowel disease and mutations affecting the interleukin-10 receptor. N. Engl. J. Med. 361, 2033-2045.

Grabinger, T., Bode, K. J., Demgenski, J., Seitz, C., Delgado, M. E., Kostadinova, F., et al. (2017). Inhibitor of apoptosis protein-1 regulates tumor necrosis factor-mediated destruction of intestinal epithelial cells. Gastroenterology 152, 867-879. doi: 10.1053/j.gastro.2016.11.019

Guidi, L., Felice, C., Procoli, A., Bonanno, G., Martinelli, E., Marzo, M., et al. (2013). FOXP3(+) $\mathrm{T}$ regulatory cell modifications in inflammatory bowel disease patients treated with anti-TNFalpha agents. Biomed. Res. Int. 2013:286368.

Gutiérrez, A., Francés, R., Amorós, A., Zapater, P., Garmendia, M., Ndongo, M., et al. (2009). Cytokine association with bacterial DNA in serum of patients with inflammatory bowel disease. Inflamm. Bowel. Dis. 15, 508-514. doi: 10.1002/ ibd.20806

Gutiérrez, A., Holler, E., Zapater, P., Sempere, L., Jover, R., Pérez-Mateo, M., et al. (2011). Antimicrobial peptide response to blood translocation of bacterial DNA in Crohn's disease is affected by NOD2/CARD15 genotype. Inflamm. Bowel. Dis. 17, 1641-1650. doi: 10.1002/ibd.21537

Gutiérrez, A., Scharl, M., Sempere, L., Holler, E., Zapater, P., Almenta, I., et al. (2014). Genetic susceptibility to increased bacterial translocation influences the response to biological therapy in patients with Crohn's disease. Gut 63, 272-280.

Gutiérrez, A., Zapater, P., Juanola, O., Sempere, L., García, M., Laveda, R., et al. (2016). Gut bacterial DNA translocation is an independent risk factor of flare at short term in patients with Crohn's disease. Am. J. Gastroenterol. 111, 529-540. doi: 10.1038/ajg.2016.8

Hampe, J., Franke, A., Rosenstiel, P., Till, A., Teuber, M., Huse, K., et al. (2007). genome-wide association scan of nonsynonymous SNPs identifies a susceptibility variant for Crohn disease in ATG16L1. Nat. Genet. 39, 207-211. doi: $10.1038 / \mathrm{ng} 1954$

Hanauer, S. B., Feagan, B. G., Lichtenstein, G. R., Mayer, L. F., Schreiber, S., Colombel, J. F., et al. (2002). Maintenance infliximab for Crohn's disease: the ACCENT I randomised trial. Lancet 359, 1541-1549. doi: 10.1016/s01406736(02)08512-4

Hara, H., Seregin, S. S., Yang, D., Fukase, K., Chamaillard, M., Alnemri, E. S., et al. (2018). The NLRP6 inflammasome recognizes lipoteichoic acid and regulates gram-positive pathogen infection. Cell 175, 1651-1664.e14.

Harper, P. H., Lee, E. C., Kettlewell, M. G., Bennett, M. K., and Jewell, D. P. (1985). Role of the faecal stream in the maintenance of Crohn's colitis. Gut 26, 279-284. doi: 10.1136/gut.26.3.279

Hart, A. L., Al-Hassi, H. O., Rigby, R. J., Bell, S. J., Emmanuel, A. V., Knight, S. C., et al. (2005). Characteristics of intestinal dendritic cells in inflammatory bowel diseases. Gastroenterology 129, 50-65.

Hayee, B., Rahman, F. Z., Tempero, J., McCartney, S., Bloom, S. L., Segal, A. W., et al. (2011). The neutrophil respiratory burst and bacterial digestion in Crohn's disease. Dig. Dis. Sci. 56, 1482-1488. doi: 10.1007/s10620-010-1426-8

Hedin, C., van der Gast, C. J., Rogers, G. B., Cuthbertson, L., McCartney, S., Stagg, A. J., et al. (2016). Siblings of patients with Crohn's disease exhibit a biologically relevant dysbiosis in mucosal microbial metacommunities. Gut 65, 944-953. doi: 10.1136/gutjnl-2014-308896

Hemmi, H., Takeuchi, O., Kawai, T., Kaisho, T., Sato, S., Sanjo, H., et al. (2000). Toll-like receptor recognizes bacterial DNA. Nature 408, 740-745. doi: 10.1038/ 35047123

Hölttä, V., Klemetti, P., Sipponen, T., Westerholm-Ormio, M., Kociubinski, G., Salo, H., et al. (2008). IL-23/IL-17 immunity as a hallmark of Crohn's disease. Inflamm. Bowel. Dis. 14, 1175-1184. doi: 10.1002/ibd.20475

Hornung, V., Ablasser, A., Charrel-Dennis, M., Bauernfeind, F., Horvath, G., Caffrey, D. R., et al. (2009). AIM2 recognizes cytosolic dsDNA and forms a caspase-1-activating inflammasome with ASC. Nature 458, 514-518. doi: 10.1038 /nature07725

Hovhannisyan, Z., Treatman, J., Littman, D. R., and Mayer, L. (2011). Characterization of interleukin-17-producing regulatory $\mathrm{T}$ cells in inflamed 
intestinal mucosa from patients with inflammatory bowel diseases. Gastroenterology 140, 957-965. doi: 10.1053/j.gastro.2010.12.002

Hrdý, J., Alard, J., Couturier-Maillard, A., Boulard, O., Boutillier, D., Delacre, M., et al. (2020). Lactobacillus reuteri 5454 and Bifidobacterium animalis ssp. lactis 5764 improve colitis while differentially impacting dendritic cells maturation and antimicrobial responses. Sci. Rep. 10:5345.

Hu, S., Peng, L., Kwak, Y. T., Tekippe, E. M., Pasare, C., Malter, J. S., et al. (2015). The DNA sensor AIM2 maintains intestinal homeostasis via regulation of epithelial antimicrobial host defense. Cell Rep. 13, 1922-1936. doi: 10.1016/ j.celrep.2015.10.040

Hueber, W., Sands, B. E., Lewitzky, S., Vandemeulebroecke, M., Reinisch, W., Higgins, P. D., et al. (2012). Secukinumab, a human anti-IL-17A monoclonal antibody, for moderate to severe Crohn's disease: unexpected results of a randomised, double-blind placebo-controlled trial. Gut 61, 1693-1700. doi: 10.1136/gutjnl-2011-301668

Hugot, J. P., Chamaillard, M., Zouali, H., Lesage, S., Cézard, J. P., Belaiche, J., et al. (2001). Association of NOD2 leucine-rich repeat variants with susceptibility to Crohn's disease. Nature 411, 599-603. doi: 10.1038/35079107

Husebye, E. (2005). The pathogenesis of gastrointestinal bacterial overgrowth. Chemotherapy 51(Suppl. 1), 1-22. doi: 10.1159/000081988

Iliev, I. D., Funari, V. A., Taylor, K. D., Nguyen, Q., Reyes, C. N., Strom, S. P., et al. (2012). Interactions between commensal fungi and the C-type lectin receptor dectin-1 influence colitis. Science 336, 1314-1317. doi: 10.1126/science.122 1789

Iliev, I. D., Spadoni, I., Mileti, E., Matteoli, G., Sonzogni, A., Sampietro, G. M., et al. (2009). Human intestinal epithelial cells promote the differentiation of tolerogenic dendritic cells. Gut 58, 1481-1489. doi: 10.1136/gut.2008.175166

Inohara, N., Ogura, Y., Fontalba, A., Gutierrez, O., Pons, F., Crespo, J., et al. (2003). Host recognition of bacterial muramyl dipeptide mediated through NOD2. implications for Crohn's disease. J. Biol. Chem. 278, 5509-5512. doi: 10.1074/jbc.c200673200

Irvine, E. J., and Marshall, J. K. (2000). Increased intestinal permeability precedes the onset of Crohn's disease in a subject with familial risk. Gastroenterology 119, 1740-1744. doi: 10.1053/gast.2000.20231

Ivanov, I. I., McKenzie, B. S., Zhou, L., Tadokoro, C. E., Lepelley, A., Lafaille, J. J., et al. (2006). The orphan nuclear receptor RORgammat directs the differentiation program of proinflammatory IL-17+ T helper cells. Cell 126, 1121-1133.

Jain, U., Ver Heul, A. M., Xiong, S., Gregory, M. H., Demers, E. G., Kern, J. T., et al. (2021). Debaryomyces is enriched in Crohn's disease intestinal tissue and impairs healing in mice. Science 371, 1154-1159. doi: 10.1126/science.abd0919

Jones-Hall, Y. L., and Nakatsu, C. H. (2016). The intersection of TNF. IBD and the Microbiome. Gut. Microbes 7, 58-62. doi: 10.1080/19490976.2015.1121364

Joossens, M., Huys, G., Cnockaert, M., De Preter, V., Verbeke, K., Rutgeerts, P., et al. (2011). Dysbiosis of the faecal microbiota in patients with Crohn's disease and their unaffected relatives. Gut 60, 631-637. doi: 10.1136/gut.2010.223263

Juanola, O., Moratalla, A., Gutiérrez, A., Sempere, L., Zapater, P., Giménez, P., et al. (2014). Anti-TNF-alpha loss of response is associated with a decreased percentage of FoxP3 $+\mathrm{T}$ cells and a variant NOD2 genotype in patients with Crohn's disease. J. Gastroenterol. 50, 758-768. doi: 10.1007/s00535-014-1020-5

Kamada, N., Hisamatsu, T., Okamoto, S., Chinen, H., Kobayashi, T., Sato, T., et al. (2008). Unique CD14 intestinal macrophages contribute to the pathogenesis of Crohn disease via IL-23/IFN-gamma axis. J. Clin. Invest. 118, 2269-2280.

Katsanos, K. H., Papamichael, K., Feuerstein, J. D., Christodoulou, D. K., and Cheifetz, A. S. (2019). Biological therapies in inflammatory bowel disease: beyond anti-TNF therapies. Clin. Immunol. 206, 9-14. doi: 10.1016/j.clim.2018. 03.004

Khan, I., Ullah, N., Zha, L., Bai, Y., Khan, A., Zhao, T., et al. (2019). Alteration of gut microbiota in inflammatory bowel disease (IBD): cause or consequence? IBD treatment targeting the gut microbiome. Pathogens 8:126. doi: 10.3390/ pathogens 8030126

Khor, B., Gardet, A., and Xavier, R. J. (2011). Genetics and pathogenesis of inflammatory bowel disease. Nature 474, 307-317.

Kim, K. S., Hong, S. W., Han, D., Yi, J., Jung, J., Yang, B. G., et al. (2016). Dietary antigens limit mucosal immunity by inducing regulatory $\mathrm{T}$ cells in the small intestine. Science 351, 858-863. doi: 10.1126/science.aac5560

Kim, S. W., Kim, E. S., Moon, C. M., Park, J. J., Kim, T. I., Kim, W. H., et al. (2011). Genetic polymorphisms of IL-23R and IL-17A and novel insights into their associations with inflammatory bowel disease. Gut 60, 1527-1536. doi: 10.1136/gut.2011.238477

Klaus, J., Spaniol, U., Adler, G., Mason, R. A., Reinshagen, M., and von Tirpitz, C. C. (2009). Small intestinal bacterial overgrowth mimicking acute flare as a pitfall in patients with Crohn's Disease. BMC Gastroenterol. 9:61.

Kobayashi, K. S., Chamaillard, M., Ogura, Y., Henegariu, O., Inohara, N., Nuñez, G., et al. (2005). Nod2-dependent regulation of innate and adaptive immunity in the intestinal tract. Science 307, 731-734. doi: 10.1126/science.1104911

Kocsis, A. K., Lakatos, P. L., Somogyvári, F., Fuszek, P., Papp, J., Fischer, S., et al. (2008). Association of beta-defensin 1 single nucleotide polymorphisms with Crohn's disease. Scand. J. Gastroenterol. 43, 299-307. doi: 10.1080/ 00365520701682615

Kosovac, K., Brenmoehl, J., Holler, E., Falk, W., Schoelmerich, J., Hausmann, M., et al. (2010). Association of the NOD2 genotype with bacterial translocation via altered cell-cell contacts in Crohn's disease patients. Inflamm. Bowel. Dis. 16, 1311-1321. doi: 10.1002/ibd.21223

Kostic, A. D., Xavier, R. J., and Gevers, D. (2014). The microbiome in inflammatory bowel disease: current status and the future ahead. Gastroenterology 146, 1489-1499. doi: 10.1053/j.gastro.2014.02.009

Kowalska-Duplaga, K., Gosiewski, T., Kapusta, P., Sroka-Oleksiak, A., Wędrychowicz, A., Pieczarkowski, S., et al. (2019). Differences in the intestinal microbiome of healthy children and patients with newly diagnosed Crohn's disease. Sci. Rep. 9:18880.

Kowalska-Duplaga, K., Kapusta, P., Gosiewski, T., Sroka-Oleksiak, A., LudwigSłomczyńska, A. H., Wołkow, P. P., et al. (2020). Changes in the intestinal microbiota are seen following treatment with infliximab in children with Crohn's disease. J. Clin. Med. 9:687. doi: 10.3390/jcm9030687

Kretschmer, K., Apostolou, I., Hawiger, D., Khazaie, K., Nussenzweig, M. C., and von Boehmer, H. (2005). Inducing and expanding regulatory $\mathrm{T}$ cell populations by foreign antigen. Nat. Immunol. 6, 1219-1227. doi: 10.1038/ni1265

Lakatos, P. L., Kiss, L. S., Palatka, K., Altorjay, I., Antal-Szalmas, P., Palyu, E., et al. (2011). Serum lipopolysaccharide-binding protein and soluble CD14 are markers of disease activity in patients with Crohn's disease. Inflamm. Bowel. Dis. 17, 767-777. doi: 10.1002/ibd.21402

Lala, S., Ogura, Y., Osborne, C., Hor, S. Y., Bromfield, A., Davies, S., et al. (2003). Crohn's disease and the NOD2 gene: a role for paneth cells. Gastroenterology 125, 47-57. doi: 10.1016/s0016-5085(03)00661-9

Lamas, B., Richard, M. L., Leducq, V., Pham, H. P., Michel, M. L., Da Costa, G., et al. (2016). CARD9 impacts colitis by altering gut microbiota metabolism of tryptophan into aryl hydrocarbon receptor ligands. Nat. Med. 22, 598-605. doi: $10.1038 / \mathrm{nm} .4102$

Langley, R. G., Elewski, B. E., Lebwohl, M., Reich, K., Griffiths, C. E., Papp, K., et al. (2014). Secukinumab in plaque psoriasis-results of two phase 3 trials. N. Engl. J. Med. 371, 326-338.

Langrish, C. L., Chen, Y., Blumenschein, W. M., Mattson, J., Basham, B., Sedgwick, J. D., et al. (2005). IL-23 drives a pathogenic T cell population that induces autoimmune inflammation. J. Exp. Med. 201, 233-240. doi: 10.1084/jem. 20041257

Lazaridis, L. D., Pistiki, A., Giamarellos-Bourboulis, E. J., Georgitsi, M., Damoraki, G., Polymeros, D., et al. (2017). Activation of NLRP3 inflammasome in inflammatory bowel disease: differences between Crohn's disease and ulcerative colitis. Dig. Dis. Sci. 62, 2348-2356. doi: 10.1007/s10620-017-4609-8

Leng, F., Yin, H., Qin, S., Zhang, K., Guan, Y., Fang, R., et al. (2020). NLRP6 selfassembles into a linear molecular platform following LPS binding and ATP stimulation. Sci. Rep. 10:198.

Liguori, G., Lamas, B., Richard, M. L., Brandi, G., da Costa, G., Hoffmann, T. W., et al. (2016). Fungal dysbiosis in mucosa-associated microbiota of Crohn's disease patients. J. Crohns Colitis 10, 296-305. doi: 10.1093/ecco-jcc/jjv209

Limketkai, B. N., Akobeng, A. K., Gordon, M., and Adepoju, A. A. (2020). Probiotics for induction of remission in Crohn's disease. Cochrane Database Syst. Rev. 7:CD006634.

Liu, L., Dong, Y., Ye, M., Jin, S., Yang, J., Joosse, M. E., et al. (2017). The pathogenic role of NLRP3 inflammasome activation in inflammatory bowel diseases of both mice and humans. J. Crohns Colitis 11, 737-750.

Liu, T. C., Gao, F., McGovern, D. P., and Stappenbeck, T. S. (2014). Spatial and temporal stability of paneth cell phenotypes in Crohn's disease: implications for prognostic cellular biomarker development. Inflamm. Bowel. Dis. 20, 646-651. doi: 10.1097/01.mib.0000442838.21040.d7 
Lloyd-Price, J., Arze, C., Ananthakrishnan, A. N., Schirmer, M., Avila-Pacheco, J., Poon, T. W., et al. (2019). Multi-omics of the gut microbial ecosystem in inflammatory bowel diseases. Nature 569, 655-662.

Lochner, M., Bérard, M., Sawa, S., Hauer, S., Gaboriau-Routhiau, V., Fernandez, T. D., et al. (2011). Restricted microbiota and absence of cognate TCR antigen leads to an unbalanced generation of Th17 cells. J. Immunol. 186, 1531-1537. doi: 10.4049/jimmunol.1001723

Lupp, C., Robertson, M. L., Wickham, M. E., Sekirov, I., Champion, O. L., Gaynor, E. C., et al. (2007). Host-mediated inflammation disrupts the intestinal microbiota and promotes the overgrowth of Enterobacteriaceae. Cell Host Microbe 2:204. doi: 10.1016/j.chom.2007.08.002

Maloy, K. J., and Powrie, F. (2011). Intestinal homeostasis and its breakdown in inflammatory bowel disease. Nature 474, 298-306. doi: 10.1038/nature10208

Manichanh, C., Borruel, N., Casellas, F., and Guarner, F. (2012). The gut microbiota in IBD. Nat. Rev. Gastroenterol. Hepatol. 9, 599-608.

Manichanh, C., Rigottier-Gois, L., Bonnaud, E., Gloux, K., Pelletier, E., Frangeul, L., et al. (2006). Reduced diversity of faecal microbiota in Crohn's disease revealed by a metagenomic approach. Gut 55, 205-211. doi: 10.1136/gut.2005.073817

Marin, M. L., Geller, S. A., Greenstein, A. J., Marin, R. H., Gordon, R. E., and Aufses, A. H. (1983a). Ultrastructural pathology of Crohn's disease: correlated transmission electron microscopy, scanning electron microscopy, and freeze fracture studies. Am. J. Gastroenterol. 78, 355-364.

Marin, M. L., Greenstein, A. J., Geller, S. A., Gordon, R. E., and Aufses, A. H. (1983b). A freeze. Am. J. Gastroenterol. 78, 537-547.

Marks, D. J., Harbord, M. W., MacAllister, R., Rahman, F. Z., Young, J., AlLazikani, B., et al. (2006). Defective acute inflammation in Crohn's disease: a clinical investigation. Lancet 367, 668-678. doi: 10.1016/s0140-6736(06)68 265-2

Martin, J. C., Bériou, G., Heslan, M., Bossard, C., Jarry, A., Abidi, A., et al. (2016). IL-22BP is produced by eosinophils in human gut and blocks IL-22 protective actions during colitis. Mucosal. Immunol. 9, 539-549. doi: 10.1038/mi.2015.83

Martínez-Borra, J., López-Larrea, C., González, S., Fuentes, D., Dieguez, A., Deschamps, E. M., et al. (2002). High serum tumor necrosis factor-alpha levels are associated with lack of response to infliximab in fistulizing Crohn's disease. Am. J. Gastroenterol. 97, 2350-2356. doi: 10.1016/s0002-9270(02)04347-2

Maser, E. A., Villela, R., Silverberg, M. S., and Greenberg, G. R. (2006). Association of trough serum infliximab to clinical outcome after scheduled maintenance treatment for Crohn's disease. Clin. Gastroenterol. Hepatol. 4, 1248-1254. doi: 10.1016/j.cgh.2006.06.025

Maul, J., Loddenkemper, C., Mundt, P., Berg, E., Giese, T., Stallmach, A., et al. (2005). Peripheral and intestinal regulatory CD4+ CD25(high) $\mathrm{T}$ cells in inflammatory bowel disease. Gastroenterology 128, 1868-1878. doi: 10.1053/ j.gastro.2005.03.043

McElroy, S. J., Prince, L. S., Weitkamp, J. H., Reese, J., Slaughter, J. C., and Polk, D. B. (2011). Tumor necrosis factor receptor 1-dependent depletion of mucus in immature small intestine: a potential role in neonatal necrotizing enterocolitis. Am. J. Physiol. Gastrointest Liver Physiol. 301, G656-G666.

McGeachy, M. J., Chen, Y., Tato, C. M., Laurence, A., Joyce-Shaikh, B., Blumenschein, W. M., et al. (2009). The interleukin 23 receptor is essential for the terminal differentiation of interleukin 17-producing effector $\mathrm{T}$ helper cells in vivo. Nat. Immunol. 10, 314-324.

McNees, A. L., Markesich, D., Zayyani, N. R., and Graham, D. Y. (2015). Mycobacterium paratuberculosis as a cause of Crohn's disease. Expert Rev. Gastroenterol. Hepatol. 9, 1523-1534.

Medzhitov, R., and Janeway, C. A. (2002). Decoding the patterns of self and nonself by the innate immune system. Science 296, 298-300. doi: 10.1126/science. 1068883

Metwaly, A., Dunkel, A., Waldschmitt, N., Raj, A. C. D., Lagkouvardos, I., Corraliza, A. M., et al. (2020). Integrated microbiota and metabolite profiles link Crohn's disease to sulfur metabolism. Nat. Commun. 11:4322.

Middel, P., Raddatz, D., Gunawan, B., Haller, F., and Radzun, H. J. (2006). Increased number of mature dendritic cells in Crohn's disease: evidence for a chemokine mediated retention mechanism. Gut 55, 220-227. doi: 10.1136/gut. 2004.063008

Mishina, D., Katsel, P., Brown, S. T., Gilberts, E. C., and Greenstein, R. J. (1996). On the etiology of Crohn disease. Proc. Natl. Acad. Sci. U.S.A. 93, 9816-9820.

Monteleone, G., Biancone, L., Marasco, R., Morrone, G., Marasco, O., Luzza, F., et al. (1997). Interleukin 12 is expressed and actively released by Crohn's disease intestinal lamina propria mononuclear cells. Gastroenterology 112, 1169-1178. doi: 10.1016/s0016-5085(97)70128-8

Moore, C., Corbett, G., and Moss, A. C. (2016). Systematic review and metaanalysis: serum infliximab levels during maintenance therapy and outcomes in inflammatory bowel disease. J. Crohns Colitis 10, 619-625. doi: 10.1093/eccojcc/jjw007

Mow, W. S., Vasiliauskas, E. A., Lin, Y. C., Fleshner, P. R., Papadakis, K. A., Taylor, K. D., et al. (2004). Association of antibody responses to microbial antigens and complications of small bowel Crohn's disease. Gastroenterology 126, 414-424. doi: 10.1053/j.gastro.2003.11.015

Muise, A. M., Walters, T. D., Glowacka, W. K., Griffiths, A. M., Ngan, B. Y., Lan, H., et al. (2009). Polymorphisms in E-cadherin (CDH1) result in a mis-localised cytoplasmic protein that is associated with Crohn's disease. Gut 58, 1121-1127. doi: 10.1136/gut.2008.175117

Nagao-Kitamoto, H., Shreiner, A. B., Gillilland, M. G., Kitamoto, S., Ishii, C., Hirayama, A., et al. (2016). Functional characterization of inflammatory bowel disease-associated gut dysbiosis in gnotobiotic mice. Cell Mol. Gastroenterol. Hepatol. 2, 468-481. doi: 10.1016/j.jcmgh.2016.02.003

Narushima, S., Sugiura, Y., Oshima, K., Atarashi, K., Hattori, M., Suematsu, M., et al. (2014). Characterization of the 17 strains of regulatory $\mathrm{T}$ cell-inducing human-derived clostridia. Gut. Microbes 5, 333-339. doi: 10.4161/gmic.28572

Naser, S. A., Ghobrial, G., Romero, C., and Valentine, J. F. (2004). Culture of Mycobacterium avium subspecies paratuberculosis from the blood of patients with Crohn's disease. Lancet 364, 1039-1044. doi: 10.1016/s0140-6736(04) 17058-x

Neurath, M. F. (2017). Current and emerging therapeutic targets for IBD. Nat. Rev. Gastroenterol. Hepatol. 14, 269-278. doi: 10.1038/nrgastro.2016.208

Ng, S. C., Benjamin, J. L., McCarthy, N. E., Hedin, C. R., Koutsoumpas, A., Plamondon, S., et al. (2011). Relationship between human intestinal dendritic cells, gut microbiota, and disease activity in Crohn's disease. Inflamm. Bowel. Dis. 17, 2027-2037. doi: 10.1002/ibd.21590

Ng, S. C., Shi, H. Y., Hamidi, N., Underwood, F. E., Tang, W., Benchimol, E. I., et al. (2017). Worldwide incidence and prevalence of inflammatory bowel disease in the 21st century: a systematic review of population-based studies. Lancet 390, 2769-2778. doi: 10.1016/s0140-6736(17)32448-0

Nguyen, G. C., Kaplan, G. G., Harris, M. L., and Brant, S. R. (2008). A national survey of the prevalence and impact of Clostridium difficile infection among hospitalized inflammatory bowel disease patients. Am. J. Gastroenterol. 103, 1443-1450. doi: 10.1111/j.1572-0241.2007.01780.x

Nielsen, O. H., Kirman, I., Rüdiger, N., Hendel, J., and Vainer, B. (2003). Upregulation of interleukin-12 and -17 in active inflammatory bowel disease. Scand. J. Gastroenterol. 38, 180-185. doi: 10.1080/00365520310000672

Norman, J. M., Handley, S. A., Baldridge, M. T., Droit, L., Liu, C. Y., Keller, B. C., et al. (2015). Disease-specific alterations in the enteric virome in inflammatory bowel disease. Cell 160, 447-460.

O’Brien, C. L., Pavli, P., Gordon, D. M., and Allison, G. E. (2014). Detection of bacterial DNA in lymph nodes of Crohn's disease patients using high throughput sequencing. Gut 63, 1596-1606. doi: 10.1136/gutjnl-2013-305320

O'Connor, W., Kamanaka, M., Booth, C. J., Town, T., Nakae, S., Iwakura, Y., et al. (2009). A protective function for interleukin 17A in T cell-mediated intestinal inflammation. Nat. Immunol. 10, 603-609. doi: 10.1038/ni.1736

Ogawa, K., Matsumoto, T., Esaki, M., Torisu, T., and Iida, M. (2012). Profiles of circulating cytokines in patients with Crohn's disease under maintenance therapy with infliximab. J. Crohns Colitis 6, 529-535. doi: 10.1016/j.crohns. 2011.10.010

Ohnmacht, C., Park, J. H., Cording, S., Wing, J. B., Atarashi, K., Obata, Y., et al. (2015). Mucosal immunology. the microbiota regulates type 2 immunity through ROR $\gamma \mathrm{t}^{+}$T cells. Science 349, 989-993.

Okamoto, R., and Watanabe, M. (2016). Role of epithelial cells in the pathogenesis and treatment of inflammatory bowel disease. J. Gastroenterol. 51, 11-21. doi: 10.1007/s00535-015-1098-4

Okou, D. T., Mondal, K., Faubion, W. A., Kobrynski, L. J., Denson, L. A., Mulle, J. G., et al. (2014). Exome sequencing identifies a novel FOXP3 mutation in a 2-generation family with inflammatory bowel disease. J. Pediatr. Gastroenterol. Nutr. 58, 561-568. doi: 10.1097/mpg.0000000000000302

Okumura, R., and Takeda, K. (2017). Roles of intestinal epithelial cells in the maintenance of gut homeostasis. Exp. Mol. Med. 49:e338. doi: 10.1038/emm. 2017.20 
O’Mahony, C., Scully, P., O’Mahony, D., Murphy, S., O’Brien, F., Lyons, A., et al. (2008). Commensal-induced regulatory $\mathrm{T}$ cells mediate protection against pathogen-stimulated NF-kappaB activation. PLoS Pathog. 4:e1000112. doi: 10. 1371/journal.ppat.1000112

O’Neil, D. A., Porter, E. M., Elewaut, D., Anderson, G. M., Eckmann, L., Ganz, T., et al. (1999). Expression and regulation of the human beta-defensins hBD-1 and hBD-2 in intestinal epithelium. J. Immunol. 163, 6718-6724.

Papamichael, K., Vande Casteele, N., Ferrante, M., Gils, A., and Cheifetz, A. S. (2017). Therapeutic drug monitoring during induction of anti-tumor necrosis factor therapy in inflammatory bowel disease: defining a therapeutic drug window. Inflamm. Bowel. Dis. 23, 1510-1515. doi: 10.1097/mib. 0000000000001231

Parkes, M., Barrett, J. C., Prescott, N. J., Tremelling, M., Anderson, C. A., Fisher, S. A., et al. (2007). Sequence variants in the autophagy gene IRGM and multiple other replicating loci contribute to Crohn's disease susceptibility. Nat. Genet 39, 830-832. doi: 10.1038/ng2061

Parronchi, P., Romagnani, P., Annunziato, F., Sampognaro, S., Becchio, A., Giannarini, L., et al. (1997). Type 1 T-helper cell predominance and interleukin12 expression in the gut of patients with Crohn's disease. Am. J. Pathol. 150, $823-832$.

Pastor Rojo, O., López San Román, A., Albéniz Arbizu, E., de la Hera Martínez, A., Ripoll Sevillano, E., and Albillos Martínez, A. (2007). Serum lipopolysaccharide-binding protein in endotoxemic patients with inflammatory bowel disease. Inflamm. Bowel. Dis. 13, 269-277. doi: 10.1002/ibd.20019

Patnaude, L., Mayo, M., Mario, R., Wu, X., Knight, H., Creamer, K., et al. (2021). Mechanisms and regulation of IL-22-mediated intestinal epithelial homeostasis and repair. Life Sci. 271:119195. doi: 10.1016/j.lfs.2021.119195

Perera, A. P., Fernando, R., Shinde, T., Gundamaraju, R., Southam, B., Sohal, S. S., et al. (2018). MCC950, a specific small molecule inhibitor of NLRP3 inflammasome attenuates colonic inflammation in spontaneous colitis mice. Sci. Rep. 8:8618.

Petnicki-Ocwieja, T., Hrncir, T., Liu, Y. J., Biswas, A., Hudcovic, T., TlaskalovaHogenova, H., et al. (2009). Nod2 is required for the regulation of commensal microbiota in the intestine. Proc. Natl. Acad. Sci. U.S.A. 106, 15813-15818. doi: 10.1073/pnas.0907722106

Peyrin-Biroulet, L., Gonzalez, F., Dubuquoy, L., Rousseaux, C., Dubuquoy, C., Decourcelle, C., et al. (2012). Mesenteric fat as a source of C reactive protein and as a target for bacterial translocation in Crohn's disease. Gut 61, 78-85. doi: 10.1136/gutjnl-2011-300370

Pignata, C., Budillon, G., Monaco, G., Nani, E., Cuomo, R., Parrilli, G., et al. (1990). Jejunal bacterial overgrowth and intestinal permeability in children with immunodeficiency syndromes. Gut 31, 879-882. doi: 10.1136/gut.31.8.879

Piñero, P., Juanola, O., Gutiérrez, A., Zapater, P., Giménez, P., Steinert, A., et al. (2017). IL26 modulates cytokine response and anti-TNF consumption in Crohn's disease patients with bacterial DNA. J. Mol. Med. (Berl) 95, 1227-1236. doi: 10.1007/s00109-017-1585-6

Pizarro, T. T., Michie, M. H., Bentz, M., Woraratanadharm, J., Smith, M. F., Foley, E., et al. (1999). IL-18, a novel immunoregulatory cytokine, is up-regulated in Crohn's disease: expression and localization in intestinal mucosal cells. J. Immunol. 162, 6829-6835.

Pochard, C., Coquenlorge, S., Jaulin, J., Cenac, N., Vergnolle, N., Meurette, G., et al. (2016). Defects in 15-HETE production and control of epithelial permeability by human enteric glial cells from patients with Crohn's disease. Gastroenterology 150, 168-180. doi: 10.1053/j.gastro.2015.09.038

Povoleri, G. A. M., Nova-Lamperti, E., Scottà, C., Fanelli, G., Chen, Y. C., Becker, P. D., et al. (2018). Human retinoic acid-regulated CD161. Nat. Immunol. 19, 1403-1414.

Qiao, Y. Q., Huang, M. L., Xu, A. T., Zhao, D., Ran, Z. H., and Shen, J. (2013). LncRNA DQ786243 affects Treg related CREB and Foxp3 expression in Crohn's disease. J. Biomed. Sci. 20:87. doi: 10.1186/1423-0127-20-87

Rahman, M. K., Midtling, E. H., Svingen, P. A., Xiong, Y., Bell, M. P., Tung, J., et al. (2010). The pathogen recognition receptor NOD2 regulates human FOXP3+ T cell survival. J. Immunol. 184, 7247-7256. doi: 10.4049/jimmunol.0901479

Raker, V. K., Domogalla, M. P., and Steinbrink, K. (2015). Tolerogenic dendritic cells for regulatory T cell induction in man. Front. Immunol. 6:569.

Ramasundara, M., Leach, S. T., Lemberg, D. A., and Day, A. S. (2009). Defensins and inflammation: the role of defensins in inflammatory bowel disease. J. Gastroenterol Hepatol. 24, 202-208. doi: 10.1111/j.1440-1746.2008.05772.x
Razik, R., Rumman, A., Bahreini, Z., McGeer, A., and Nguyen, G. C. (2016). Recurrence of Clostridium difficile infection in patients with inflammatory bowel disease: the recidivism study. Am. J. Gastroenterol. 111, 1141-1146. doi: 10.1038/ajg.2016.187

Rescigno, M., Urbano, M., Valzasina, B., Francolini, M., Rotta, G., Bonasio, R., et al. (2001). Dendritic cells express tight junction proteins and penetrate gut epithelial monolayers to sample bacteria. Nat. Immunol. 2, 361-367. doi: 10. $1038 / 86373$

Ribaldone, D. G., Caviglia, G. P., Abdulle, A., Pellicano, R., Ditto, M. C., Morino, M., et al. (2019). Adalimumab therapy improves intestinal dysbiosis in Crohn's disease. J. Clin. Med. 8:1646. doi: 10.3390/jcm8101646

Rioux, J. D., Xavier, R. J., Taylor, K. D., Silverberg, M. S., Goyette, P., Huett, A., et al. (2007). Genome-wide association study identifies new susceptibility loci for Crohn disease and implicates autophagy in disease pathogenesis. Nat. Genet 39, 596-604. doi: 10.1038/ng2032

Roncarolo, M. G., Gregori, S., Battaglia, M., Bacchetta, R., Fleischhauer, K., and Levings, M. K. (2006). Interleukin-10-secreting type 1 regulatory T cells in rodents and humans. Immunol. Rev. 212, 28-50. doi: 10.1111/j.0105-2896. 2006.00420.x

Round, J. L., and Mazmanian, S. K. (2010). Inducible Foxp3+ regulatory T-cell development by a commensal bacterium of the intestinal microbiota. Proc. Natl. Acad. Sci. U.S.A. 107, 12204-12209. doi: 10.1073/pnas.0909122107

Rubino, S. J., Selvanantham, T., Girardin, S. E., and Philpott, D. J. (2012). Nod-like receptors in the control of intestinal inflammation. Curr. Opin. Immunol. 24, 398-404. doi: 10.1016/j.coi.2012.04.010

Rutgeerts, P., D’Haens, G., Targan, S., Vasiliauskas, E., Hanauer, S. B., Present, D. H., et al. (1999). Efficacy and safety of retreatment with anti-tumor necrosis factor antibody (infliximab) to maintain remission in Crohn's disease. Gastroenterology 117, 761-769. doi: 10.1016/s0016-5085(99)70332-x

Sakaguchi, S., Miyara, M., Costantino, C. M., and Hafler, D. A. (2010). FOXP3+ regulatory $\mathrm{T}$ cells in the human immune system. Nat. Rev. Immunol. 10, 490-500. doi: 10.1038/nri2785

Sakuraba, A., Sato, T., Kamada, N., Kitazume, M., Sugita, A., and Hibi, T. (2009). Th1/Th17 immune response is induced by mesenteric lymph node dendritic cells in Crohn's disease. Gastroenterology 137, 1736-1745. doi: 10.1053/j.gastro. 2009.07.049

Salim, S. Y., and Söderholm, J. D. (2011). Importance of disrupted intestinal barrier in inflammatory bowel diseases. Inflamm. Bowel. Dis. 17, 362-381. doi: 10.1002/ibd.21403

Sands, B. E., Anderson, F. H., Bernstein, C. N., Chey, W. Y., Feagan, B. G., Fedorak, R. N., et al. (2004). Infliximab maintenance therapy for fistulizing Crohn's disease. N. Engl. J. Med. 350, 876-885.

Sands, B. E., Chen, J., Feagan, B. G., Penney, M., Rees, W. A., Danese, S., et al. (2017). Efficacy and safety of MEDI2070, an antibody against interleukin 23 , in patients with moderate to severe Crohn's disease: a phase 2a study. Gastroenterology 153, 77-86.e6.

Sartor, R. B. (2008). Microbial influences in inflammatory bowel diseases. Gastroenterology 134, 577-594. doi: 10.1053/j.gastro.2007.11.059

Schauber, J., Rieger, D., Weiler, F., Wehkamp, J., Eck, M., Fellermann, K., et al. (2006). Heterogeneous expression of human cathelicidin hCAP18/LL-37 in inflammatory bowel diseases. Eur. J. Gastroenterol. Hepatol. 18, 615-621. doi: 10.1097/00042737-200606000-00007

Schilderink, R., Verseijden, C., Seppen, J., Muncan, V., van den Brink, G. R., Lambers, T. T., et al. (2016). The SCFA butyrate stimulates the epithelial production of retinoic acid via inhibition of epithelial HDAC. Am. J. Physiol. Gastrointest Liver Physiol. 310, G1138-G1146.

Schroeder, B. O., Wu, Z., Nuding, S., Groscurth, S., Marcinowski, M., Beisner, J., et al. (2011). Reduction of disulphide bonds unmasks potent antimicrobial activity of human $\beta$-defensin 1 . Nature 469, 419-423. doi: 10.1038/nature0 9674

Schwartz, D., Shafran, I., Romero, C., Piromalli, C., Biggerstaff, J., Naser, N., et al. (2000). Use of short-term culture for identification of Mycobacterium avium subsp. paratuberculosis in tissue from Crohn's disease patients. Clin. Microbiol. Infect. 6, 303-307. doi: 10.1046/j.1469-0691.2000.00093.x

Sefik, E., Geva-Zatorsky, N., Oh, S., Konnikova, L., Zemmour, D., McGuire, A. M., et al. (2015). Mucosal immunology. individual intestinal symbionts induce a distinct population of $\mathrm{ROR} \gamma^{+}$regulatory T cells. Science 349, 993-997. doi: $10.1126 /$ science.aaa9420 
Segal, A. W. (2018). The role of neutrophils in the pathogenesis of Crohn's disease. Eur. J. Clin. Invest. 48(Suppl. 2):e12983.

Segal, A. W., and Loewi, G. (1976). Neutrophil dysfunction in Crohn's disease. Lancet 2, 219-221. doi: 10.1016/s0140-6736(76)91024-2

Seiderer, J., Elben, I., Diegelmann, J., Glas, J., Stallhofer, J., Tillack, C., et al. (2008). Role of the novel Th17 cytokine IL-17F in inflammatory bowel disease (IBD): upregulated colonic IL-17F expression in active Crohn's disease and analysis of the IL17F p.His161Arg polymorphism in IBD. Inflamm. Bowel. Dis. 14, 437-445. doi: 10.1002/ibd.20339

Senhaji, N., Kojok, K., Darif, Y., Fadainia, C., and Zaid, Y. (2015). The contribution of $\mathrm{CD} 40 / \mathrm{CD} 40 \mathrm{~L}$ axis in inflammatory bowel disease: an update. Front. Immunol. 6:529.

Seong, G., Kim, N., Joung, J. G., Kim, E. R., Chang, D. K., Chun, J., et al. (2020). Changes in the intestinal microbiota of patients with inflammatory bowel disease with clinical remission during an 8-week infliximab infusion cycle. Microorganisms 8:874. doi: 10.3390/microorganisms 8060874

Seow, C. H., Stempak, J. M., Xu, W., Lan, H., Griffiths, A. M., Greenberg, G. R., et al. (2009). Novel anti-glycan antibodies related to inflammatory bowel disease diagnosis and phenotype. Am. J. Gastroenterol. 104, 1426-1434. doi: 10.1038/ ajg. 2009.79

Silverberg, M. S., Cho, J. H., Rioux, J. D., McGovern, D. P., Wu, J., Annese, V., et al. (2009). Ulcerative colitis-risk loci on chromosomes 1p36 and 12q15 found by genome-wide association study. Nat. Genet 41, 216-220.

Singh, S., Bhatia, R., Khare, P., Sharma, S., Rajarammohan, S., Bishnoi, M., et al. (2020). Anti-inflammatory Bifidobacterium strains prevent dextran sodium sulfate induced colitis and associated gut microbial dysbiosis in mice. Sci. Rep. 10:18597.

Smith, A. M., Rahman, F. Z., Hayee, B., Graham, S. J., Marks, D. J., Sewell, G. W., et al. (2009). Disordered macrophage cytokine secretion underlies impaired acute inflammation and bacterial clearance in Crohn's disease. J. Exp. Med. 206, 1883-1897. doi: 10.1084/jem.20091233

Smith, P. M., Howitt, M. R., Panikov, N., Michaud, M., Gallini, C. A., Bohlooly-Y, M., et al. (2013). The microbial metabolites, short-chain fatty acids, regulate colonic Treg cell homeostasis. Science 341, 569-573. doi: 10.1126/science. 1241165

Song-Zhao, G. X., Srinivasan, N., Pott, J., Baban, D., Frankel, G., and Maloy, K. J. (2014). Nlrp3 activation in the intestinal epithelium protects against a mucosal pathogen. Mucosal. Immunol. 7, 763-774. doi: 10.1038/mi.2013.94

Sonnenberg, G. F., and Artis, D. (2012). Innate lymphoid cell interactions with microbiota: implications for intestinal health and disease. Immunity 37, 601610. doi: $10.1016 /$ j.immuni.2012.10.003

Stritesky, G. L., Yeh, N., and Kaplan, M. H. (2008). IL-23 promotes maintenance but not commitment to the Th17 lineage. J. Immunol. 181, 5948-5955. doi: 10.4049/jimmunol.181.9.5948

Strober, W., and Fuss, I. J. (2011). Proinflammatory cytokines in the pathogenesis of inflammatory bowel diseases. Gastroenterology 140, 1756-1767. doi: 10.1053/ j.gastro.2011.02.016

Sugimoto, K., Ogawa, A., Mizoguchi, E., Shimomura, Y., Andoh, A., Bhan, A. K., et al. (2008). IL-22 ameliorates intestinal inflammation in a mouse model of ulcerative colitis. J. Clin. Invest. 118, 534-544.

Swank, G. M., and Deitch, E. A. (1996). Role of the gut in multiple organ failure: bacterial translocation and permeability changes. World J. Surg. 20, 411-417. doi: $10.1007 /$ s002689900065

Tait Wojno, E. D., Hunter, C. A., and Stumhofer, J. S. (2019). The immunobiology of the interleukin-12 family: room for discovery. Immunity 50, 851-870.

Takesue, Y., Ohge, H., Uemura, K., Imamura, Y., Murakami, Y., Yokoyama, T., et al. (2002). Bacterial translocation in patients with Crohn's disease undergoing surgery. Dis. Colon. Rectum. 45, 1665-1671. doi: 10.1007/s10350-004-7 $256-\mathrm{z}$

Takeuchi, K., Smale, S., Premchand, P., Maiden, L., Sherwood, R., Thjodleifsson, B., et al. (2006). Prevalence and mechanism of nonsteroidal anti-inflammatory drug-induced clinical relapse in patients with inflammatory bowel disease. Clin. Gastroenterol. Hepatol. 4, 196-202. doi: 10.1016/s1542-3565(05)00980-8

Tanoue, T., Atarashi, K., and Honda, K. (2016). Development and maintenance of intestinal regulatory T cells. Nat. Rev. Immunol. 16, 295-309. doi: 10.1038/nri. 2016.36

Targan, S. R., Feagan, B., Vermeire, S., Panaccione, R., Melmed, G. Y., Landers, C., et al. (2016). A randomized, double-blind, placebo-controlled phase 2 study of brodalumab in patients with moderate-to-severe Crohn's disease. Am. J. Gastroenterol. 111, 1599-1607. doi: 10.1038/ajg.2016.298

Tecchio, C., and Cassatella, M. A. (2016). Neutrophil-derived chemokines on the road to immunity. Semin. Immunol. 28, 119-128. doi: 10.1016/j.smim.2016.04. 003

Tibble, J. A., Sigthorsson, G., Bridger, S., Fagerhol, M. K., and Bjarnason, I. (2000). Surrogate markers of intestinal inflammation are predictive of relapse in patients with inflammatory bowel disease. Gastroenterology 119, 15-22. doi: 10.1053 /gast.2000.8523

Timmer, A., Sutherland, L. R., and Martin, F. (1998). Oral contraceptive use and smoking are risk factors for relapse in Crohn's disease. the canadian mesalamine for remission of Crohn's disease study group. Gastroenterology 114, 1143-1150. doi: 10.1016/s0016-5085(98)70419-6

Torres, J., Mehandru, S., Colombel, J. F., and Peyrin-Biroulet, L. (2017). Crohn's disease. Lancet 389, 1741-1755.

Torres, J., Petralia, F., Sato, T., Wang, P., Telesco, S. E., Choung, R. S., et al. (2020). Serum biomarkers identify patients who will develop inflammatory bowel diseases up to 5 years before diagnosis. Gastroenterology 159, 96-104. doi: 10.1053/j.gastro.2020.03.007

Tran, D. H., Wang, J., Ha, C., Ho, W., Mattai, S. A., Oikonomopoulos, A., et al. (2017). Circulating cathelicidin levels correlate with mucosal disease activity in ulcerative colitis, risk of intestinal stricture in Crohn's disease, and clinical prognosis in inflammatory bowel disease. BMC Gastroenterol. 17:63.

Trotta, E., Bessette, P. H., Silveria, S. L., Ely, L. K., Jude, K. M., Le, D. T., et al. (2018). A human anti-IL-2 antibody that potentiates regulatory T cells by a structurebased mechanism. Nat. Med. 24, 1005-1014. doi: 10.1038/s41591-018-0 070-2

Tsuji, N. M., and Kosaka, A. (2008). Oral tolerance: intestinal homeostasis and antigen-specific regulatory T cells. Trends Immunol. 29, 532-540. doi: 10.1016/ j.it.2008.09.002

Turner, J. R. (2009). Intestinal mucosal barrier function in health and disease. Nat. Rev. Immunol. 9, 799-809. doi: 10.1038/nri2653

Turpin, W., Lee, S. H., Raygoza Garay, J. A., Madsen, K. L., Meddings, J. B., Bedrani, L., et al. (2020). Increased intestinal permeability is associated with later development of Crohn's disease. Gastroenterology 159, 2092-2100.e5.

Ueno, A., Jijon, H., Chan, R., Ford, K., Hirota, C., Kaplan, G. G., et al. (2013). Increased prevalence of circulating novel IL-17 secreting Foxp3 expressing $\mathrm{CD} 4+\mathrm{T}$ cells and defective suppressive function of circulating Foxp3+ regulatory cells support plasticity between Th17 and regulatory $\mathrm{T}$ cells in inflammatory bowel disease patients. Inflamm. Bowel. Dis. 19, 2522-2534. doi: 10.1097/mib.0b013e3182a85709

VanDussen, K. L., Liu, T. C., Li, D., Towfic, F., Modiano, N., Winter, R., et al. (2014). Genetic variants synthesize to produce paneth cell phenotypes that define subtypes of Crohn's disease. Gastroenterology 146, 200-209. doi: 10. 1053/j.gastro.2013.09.048

Veldhoen, M., Hocking, R. J., Atkins, C. J., Locksley, R. M., and Stockinger, B. (2006). TGFbeta in the context of an inflammatory cytokine milieu supports de novo differentiation of IL-17-producing T cells. Immunity 24, 179-189. doi: 10.1016/j.immuni.2006.01.001

Verstege, M. I., ten Kate, F. J., Reinartz, S. M., van Drunen, C. M., Slors, F. J., Bemelman, W. A., et al. (2008). Dendritic cell populations in colon and mesenteric lymph nodes of patients with Crohn's disease. J. Histochem. Cytochem. 56, 233-241. doi: 10.1369/jhc.7a7308.2007

Visvanathan, S., Baum, P., Salas, A., Vinisko, R., Schmid, R., Grebe, K. M., et al. (2018). Selective IL-23 inhibition by risankizumab modulates the molecular profile in the colon and ileum of patients with active Crohn's disease: results from a randomised phase II biopsy sub-study. J. Crohns Colitis 12, 1170-1179. doi: 10.1093/ecco-jcc/jjy099

von Burg, N., Turchinovich, G., and Finke, D. (2015). Maintenance of immune homeostasis through ILC/T cell interactions. Front. Immunol. 6:416.

Voss, E., Wehkamp, J., Wehkamp, K., Stange, E. F., Schröder, J. M., and Harder, J. (2006). NOD2/CARD15 mediates induction of the antimicrobial peptide human beta-defensin-2. J. Biol. Chem. 281, 2005-2011. doi: 10.1074/jbc. $\mathrm{m} 511044200$

Wagner, H. (2002). Interactions between bacterial CpG-DNA and TLR9 bridge innate and adaptive immunity. Curr. Opin. Microbiol. 5, 62-69. doi: 10.1016/ s1369-5274(02)00287-4 
Wehkamp, J., Harder, J., Weichenthal, M., Schwab, M., Schäffeler, E., Schlee, M., et al. (2004). NOD2 (CARD15) mutations in Crohn's disease are associated with diminished mucosal alpha-defensin expression. Gut 53, 1658-1664. doi: 10.1136/gut.2003.032805

Wehkamp, J., Salzman, N. H., Porter, E., Nuding, S., Weichenthal, M., Petras, R. E., et al. (2005). Reduced paneth cell alpha-defensins in ileal Crohn's disease. Proc. Natl. Acad. Sci. U.S.A. 102, 18129-18134.

Wéra, O., Lancellotti, P., and Oury, C. (2016). The dual role of neutrophils in inflammatory bowel diseases. J. Clin. Med. 5:118. doi: 10.3390/jcm5120118

Willing, B. P., Dicksved, J., Halfvarson, J., Andersson, A. F., Lucio, M., Zheng, Z., et al. (2010). A pyrosequencing study in twins shows that gastrointestinal microbial profiles vary with inflammatory bowel disease phenotypes. Gastroenterology 139, 1844-1854.e1.

Windsor, J. W., and Kaplan, G. G. (2019). Evolving epidemiology of IBD. Curr. Gastroenterol. Rep. 21:40.

Wlodarska, M., Thaiss, C. A., Nowarski, R., Henao-Mejia, J., Zhang, J. P., Brown, E. M., et al. (2014). NLRP6 inflammasome orchestrates the colonic host-microbial interface by regulating goblet cell mucus secretion. Cell 156, 1045-1059. doi: 10.1016/j.cell.2014.01.026

Xiao, Y. T., Yan, W. H., Cao, Y., Yan, J. K., and Cai, W. (2016). Neutralization of IL- 6 and TNF- $\alpha$ ameliorates intestinal permeability in DSS-induced colitis. Cytokine 83, 189-192. doi: 10.1016/j.cyto.2016.04.012

Xu, M., Pokrovskii, M., Ding, Y., Yi, R., Au, C., Harrison, O. J., et al. (2018). Author correction: c-MAF-dependent regulatory $\mathrm{T}$ cells mediate immunological tolerance to a gut pathobiont. Nature 554, 373-377. doi: 10.1038/nature2 5500

Xu, P., Elamin, E., Elizalde, M., Bours, P. P. H. A., Pierik, M. J., Masclee, A. A. M., et al. (2019). Modulation of intestinal epithelial permeability by plasma from patients with Crohn's disease in a three-dimensional cell culture model. Sci. Rep. 9:2030.

Yamaguchi, N., Isomoto, H., Mukae, H., Ishimoto, H., Ohnita, K., Shikuwa, S., et al. (2009). Concentrations of alpha- and beta-defensins in plasma of patients with inflammatory bowel disease. Inflamm. Res. 58, 192-197. doi: 10.1007/s00011008-8120-8

Yang, X. O., Chang, S. H., Park, H., Nurieva, R., Shah, B., Acero, L., et al. (2008). Regulation of inflammatory responses by IL-17F. J. Exp. Med. 205, 1063-1075.

Yantiss, R. K. (2015). Eosinophils in the GI tract: how many is too many and what do they mean? Mod. Pathol. 28(Suppl. 1), S7-S21.

Yilmaz, B., Juillerat, P., Øyås, O., Ramon, C., Bravo, F. D., Franc, Y., et al. (2019). Microbial network disturbances in relapsing refractory Crohn's disease. Nat. Med. 25, 323-336. doi: 10.1038/s41591-018-0308-Z

Zaki, M. H., Boyd, K. L., Vogel, P., Kastan, M. B., Lamkanfi, M., and Kanneganti, T. D. (2010). The NLRP3 inflammasome protects against loss of epithelial integrity and mortality during experimental colitis. Immunity 32, 379-391. doi: 10.1016/j.immuni.2010.03.003

Zeissig, S., Bürgel, N., Günzel, D., Richter, J., Mankertz, J., Wahnschaffe, U., et al. (2007). Changes in expression and distribution of claudin 2, 5 and 8 lead to discontinuous tight junctions and barrier dysfunction in active Crohn's disease. Gut 56, 61-72. doi: 10.1136/gut.2006.094375

Zha, J. M., Li, H. S., Lin, Q., Kuo, W. T., Jiang, Z. H., Tsai, P. Y., et al. (2019). Interleukin 22 expands transit-amplifying cells while depleting lgr5. Cell Mol. Gastroenterol. Hepatol. 7, 255-274. doi: 10.1016/j.jcmgh.2018.09.006

Zhang, M., Zhou, L., Wang, Y., Dorfman, R. G., Tang, D., Xu, L., et al. (2019). Faecalibacterium prausnitzii produces butyrate to decrease c-Myc-related metabolism and Th17 differentiation by inhibiting histone deacetylase 3. Int. Immunol. 31, 499-514. doi: 10.1093/intimm/dxz022

Zhang, R., Miao, J., and Zhu, P. (2020). Regulatory T cell heterogeneity and therapy in autoimmune diseases. Autoimmun. Rev. 20:102715. doi: 10.1016/j.autrev. 2020.102715

Zhang, X., Liu, S., Wang, Y., Hu, H., Li, L., Wu, Y., et al. (2019). Interleukin-22 regulates the homeostasis of the intestinal epithelium during inflammation. Int. J. Mol. Med. 43, 1657-1668.

Zhang, Z., Zheng, M., Bindas, J., Schwarzenberger, P., and Kolls, J. K. (2006). Critical role of IL-17 receptor signaling in acute TNBS-induced colitis. Inflamm. Bowel. Dis. 12, 382-388. doi: 10.1097/01.mib.0000218764.06959.91

Conflict of Interest: AG has served as speaker, consultant, or advisory member for, or received research funding from MSD, ABBVIE, TAKEDA, KERN PHARMA, PFIZER, OTSUKA, SHIRE, and JANSSEN, outside the submitted work.

The remaining authors declare that the research was conducted in the absence of any commercial or financial relationships that could be construed as a potential conflict of interest.

Publisher's Note: All claims expressed in this article are solely those of the authors and do not necessarily represent those of their affiliated organizations, or those of the publisher, the editors and the reviewers. Any product that may be evaluated in this article, or claim that may be made by its manufacturer, is not guaranteed or endorsed by the publisher.

Copyright (c) 2021 Linares, Francés, Gutiérrez and Juanola. This is an open-access article distributed under the terms of the Creative Commons Attribution License (CC BY). The use, distribution or reproduction in other forums is permitted, provided the original author(s) and the copyright owner(s) are credited and that the original publication in this journal is cited, in accordance with accepted academic practice. No use, distribution or reproduction is permitted which does not comply with these terms. 